\title{
A CONTROVÉRSIA DO ABORTO E A IMPRENSA NA CAMPANHA ELEITORAL DE 2010'
}

\begin{abstract}
Naara Luna*
O artigo analisa o discurso sobre aborto veiculado pela imprensa durante a campanha eleitoral de 2010. Realizou-se pesquisa qualitativa de caráter documental com levantamento sistemático da cobertura na versão impressa do jornal O Globo e busca aleatória em veículos que abordaram o tema e a relação das polêmicas eleitorais com a religião, em setembro e outubro de 2010 . O enfoque está no discurso apresentado nos artigos, os tópicos e atores repetidos. Salienta-se a participação de grupos religiosos em posições distintas não com respeito ao aborto, mas a apoios e alianças eleitorais. A análise demonstra que o aumento da frequência do tema na mídia não encetou debate sobre o problema do aborto na sociedade brasileira, mas foi usado como categoria de acusação e divisor entre candidatos, principalmente na campanha presidencial. Contrastando com o destaque dado à Igreja Católica em eventos semelhantes, a mídia revelou atores políticos e religiosos antes obscuros.

PALAVRAS-CHAvE: Aborto. Eleições de 2010. Igreja Católica. Evangélicos. Imprensa.
\end{abstract}

Este artigo analisa os discursos sobre aborto veiculados pela imprensa durante a campanha eleitoral de 2010 nos meses de setembro e outubro, quando o tema foi explorado como uma controvérsia envolvendo preferências eleitorais. $\mathrm{O}$ enfoque será dado ao discurso apresentado nos artigos, identificando os temas e atores que se repetem, com análise de caráter qualitativo de material da grande imprensa. Os principais candidatos na disputa à presidência em 2010 eram Dilma Rousseff, do Partido dos Trabalhadores (PT), José Serra do Partido da Social Democracia Brasileira (PSDB), Marina Silva, do Partido Verde (PV) e Plínio de Arruda Sampaio, do Partido Socialismo e Liberdade (PSOL). No último mês antes do primeiro turno, o tema do aborto despontou na cam-

* Doutora e pós-doutora em Antropologia. Professora adjunta do Departamento de Ciências Sociais e Extensão Rural (DCS) do Instituto de Ciências Humanas e Sociais da Universidade Federal Rural Rio de Janeiro (UFRRJ) e da Pós-Graduação em Ciências Sociais da UFRRJ.

BR 465, km 7 Cep: 23.890-000. Seropédica - Rio de Janeiro - Brasil. naaraluna@globo.com

${ }^{1}$ Artigo baseado na comunicação "A polêmica do aborto na campanha eleitoral de 2010: um estudo sobre representações na imprensa”, apresentada na IX Reunião de Antropologia do Mercosul, 10 a 13 de julho de 2011 - Curitiba. panha com especulações sobre as posições dos candidatos, em uma dinâmica de acusações que atingiu especialmente o Partido dos Trabalhadores e sua candidata, um movimento identificado inicialmente em páginas e listas da Internet (Machado, 2012; Ramos, 2012). Associado ao tema do aborto, pesquisas sobre intenções de voto indicaram a mudança de preferência de eleitores religiosos, tema de destaque na grande imprensa, que retratou as articulações de lideranças religiosas a esse respeito, além de veicular artigos de opinião sobre aborto e análises sobre comportamento eleitoral de religiosos, conforme se verá adiante neste artigo (Machado, 2012; Fontes, 2012). O tema do aborto articulou dimensões públicas e privadas dos candidatos no ciberespaço (Ramos, 2012) e na grande imprensa também. O objetivo deste artigo é analisar os discursos sobre aborto veiculados na grande imprensa durante o processo eleitoral.

Importa entender o contexto anterior a esse processo. No Brasil, estudos recentes sobre o debate legislativo no Congresso Nacional constatam que, a partir do final dos anos 90, houve uma onda conservadora contrária ao aborto (Machado, 2010; 
Gomes, 2009), em particular nas legislaturas de 1999 e 2003 (Rocha, 2006). Pesquisa em andamento mostra, na legislatura de 2007-2010 da Câmara dos Deputados, o crescimento da posição antiaborto. ${ }^{2}$

Outro aspecto a considerar é a análise da cobertura de imprensa sobre aborto em décadas anteriores: os anos de 1990 e início dos anos 2000. Ardaillon (1997, p. 378) identifica, na cobertura de imprensa, as propostas de legalização ou descriminalização do aborto voluntário e uma resposta sobre a definição de vida, seu início e fim, os estatutos de embrião, feto e criança, quem decide (a mulher, o casal), a capacidade de superação materna, e, em termos políticos, a proposta de um plebiscito. Retratando a polêmica do aborto na imprensa com base em levantamento sistemático nos anos de 1996 e 1997, Jacira Melo (1997) identifica o surgimento de novos protagonistas do debate para além das feministas: juízes, advogados, profissionais de saúde, parlamentares e entidades representativas da classe médica, como o Conselho Federal de Medicina e a Federação Brasileira das Associações de Ginecologia e Obstetrícia (FEBRASGO). Ela salienta o aumento do volume de matérias após a aprovação na Comissão de Constituição de Justiça da Câmara dos Deputados do projeto de lei que dispõe sobre a obrigatoriedade de atendimento no Sistema Único de Saúde (SUS) dos casos de aborto previstos em lei, com manifestações favoráveis e contrárias a essa regulamentação. Melo constata que a Igreja Católica é uma "referência imprescindível para as matérias sobre aborto", mesmo quando a notícia está voltada para o campo legislativo, judiciário ou da saúde. Outro ponto é o debate ético-religioso com o destaque, no período, para a consolidação das católicas feministas como ator social na figura da organização não governamental (ONG) Católicas pelo Direito de Decidir. Em texto de 2002, referente à cobertura

${ }^{2}$ No quadriênio de 2007-2010, dos 278 discursos proferidos com a palavra aborto, 70,1\% (195) foram antiaborto, $17,3 \%$ (48) pró-escolha e 12,6\% (35) não definiram posição; das proposições legislativas, houve 35 antiaborto e 9 pró-escolha, segundo resultados do projeto "Do aborto à pesquisa com células-tronco embrionárias: o estatuto de embriões e fetos e o debate sobre direitos humanos no Brasil”, financiado pelo auxílio APQ1 da Fundação de Apoio à Pesquisa do Rio de Janeiro (FAPERJ). da imprensa na década de 1990, as novidades são a implantação de serviços de aborto legal, o que incluiu uma diversidade maior de vozes, como a de profissionais de saúde, operadores de Direito e de mulheres usuárias de tais serviços. Também nova é a discussão sobre aborto em casos de malformação fetal grave, com envolvimento de juízes, profissionais de saúde e as mulheres. Outro ponto importante é a defesa do direito à vida, mobilizada não apenas pela Conferência Nacional dos Bispos do Brasil (CNBB), mas por deputados católicos e evangélicos. No período, foram veiculadas pesquisas de opinião pública que mostram aceitação crescente do direito ao aborto nos casos previstos em lei (estupro e risco de vida da gestante) (Melo, 2002).

Se a cobertura do aborto na imprensa apresenta características que se repetem, no contexto pesquisado, o quadro das eleições dota o surgimento desse tema de um matiz muito específico, no qual se chocam atores com diversas posições. O caso da disputa ao Senado da médica e então deputada federal (PCdoB) Jandira Feghali exemplifica bem essa questão: sua candidatura perdeu força na reta final em função de uma campanha dirigida pela Igreja Católica, que associava a candidata à reforma da lei sobre aborto, o que teria influenciado os votos de eleitores católicos (Gomes; Menezes, 2008). ${ }^{3}$ No contorno da campanha eleitoral de 2010, embora o tópico aborto tenha aflorado com referência a candidaturas ao governo de estados e ao Senado, conforme se verá adiante, o tema alcançou proporções muito maiores no quadro da disputa presidencial. Mais do que o questionamento a posições pessoais, o modo como ocorreu a cobertura do tema do aborto pela grande imprensa assumiu a proporção de uma controvérsia, envolvendo, além dos principais candidatos, outros atores sociais, dentre os quais se destacaram os religiosos. O presente artigo analisa a cober-

\footnotetext{
Não faz parte do objetivo desse artigo, mas, em rápida busca pela internet, encontraram-se indagações relativas aos posicionamentos de candidatos sobre o aborto em diversas disputas eleitorais. Entre os exemplos, está o de Maluf questionando Covas em debate do primeiro turno da eleição presidencial de 1989, além das acusações da ex-namorada de Lula já no segundo turno daquela eleição (exemplo que será analisado adiante).
} 
tura da imprensa sobre o tema do aborto, na cobertura da campanha eleitoral de 2010, como uma controvérsia. Emprega-se o conceito de controvérsia conforme é definido por Giumbelli (2002b, p. 96-97):

Quando se observa uma polêmica, na qual, acerca de um dado assunto, intervém uma série de agentes sociais, pode-se tratá-la apenas como uma convulsão efêmera, fadada a arrefecer tão logo outros assuntos ganhem o centro das atenções. De fato, é assim que se passa com a maioria das controvérsias. No entanto, sem negar sua ocorrência passageira, pode-se considerá-las como um momento de expressão e redefinição de pontos e problemas, os quais permanecem importantes, às vezes até cruciais, na constituição de uma sociedade, mesmo quando não despertam interesse generalizado ou intenso. Se é apenas em determinadas ocasiões que se polemiza sobre "religião", isso não quer dizer que essa noção não seja essencial para entender traços constitutivos da sociedade de que fazem parte as personagens da controvérsia. A controvérsia é uma espécie de drama social, que revela, mas também reconfigura definições de realidade, explicitando o conflito que existe em torno dessas definições.

Acredita-se que a controvérsia sobre o aborto, na campanha eleitoral, é um momento privilegiado para verificar a expressão e a redefinição de pontos e problemas cruciais na constituição de uma sociedade, como no caso em questão. Este artigo, como já foi mencionado, analisa os discursos proferidos sobre aborto na imprensa durante a campanha eleitoral de 2010, nos meses de setembro e outubro. A metodologia consiste na realização de levantamento sistemático da cobertura no jornal $O$ Globo em sua versão impressa, e busca aleatória em outros veículos em que o tema foi matéria de primeira página, como nos jornais $O$ Estado de $S$. Paulo e Folha de S. Paulo, bem como as revistas Veja, Época e Carta Capital, que tiveram matéria de capa relacionada ao tema, ou à relação das polêmicas eleitorais com a religião. Pretende-se descrever o material coletado seguindo a cronologia, a fim de abordar esse processo em uma perspectiva histórica, mostrando o desenrolar de um debate e como foram construídas posições e oposições.

Como controle, fez-se um levantamento, nos doze meses do ano de 2010, com busca da palavra-chave aborto, nos jornais $O$ Globo e Folha de
São Paulo (Folha.com), em sua versão eletrônica.

Folha de S. Paulo. Na versão eletrônica, Folha.com, a palavra aborto foi encontrada em todos os meses de 2010 em diferentes proporções. ${ }^{4}$ Há um aumento súbito na frequência da palavra no mês de outubro, quando aconteceram o primeiro e o segundo turno das eleições: de 531 notícias com a palavra no ano, 203 são publicadas em outubro, ou seja, mais de $38 \%$.

O Globo. Na versão eletrônica desse jornal, a palavra aborto (presente em todos os meses do ano) aparece em 1.134 notícias, número maior do que o encontrado na Folha.com. ${ }^{5}$ Mais da metade das notícias do ano aparece no mês de outubro (583), aumento semelhante ao do outro jornal pesquisado. Levantamento quantitativo sistemático realizado pelo Observatório da Imprensa em 29 publicações de $1^{\circ}$ de setembro a 19 de outubro confirma essa tendência. ${ }^{6}$ A partir desses dados, Lopes (2010), do Observatório da Imprensa, afirma que “[...] a grande imprensa exerceu um papel fundamental no agendamento do tema aborto, com intuitos eleitorais muito evidentes". Pretende-se, a seguir, como foi dito, reportar cronologicamente, a partir das datas das notícias, o que surgiu nesse debate. Haverá uma descrição mais detida dos artigos de opinião e das reportagens sobre o tema aborto.

\section{A COBERTURA NO MÊS DE SETEMBRO}

Serão destacados, aqui, os pontos mais importantes da cobertura de $O$ Globo (versões impressa e digital) e da Folha.com no mês de setembro.

Nesse mês, uma notícia se destaca logo em seu primeiro dia: "Marina diz que adversários

${ }^{4}$ Em janeiro: a palavra aborto foi mencionada em 25 notícias; fevereiro, 19; março, 35; abril, 23; maio, 40; junho, 25; julho, 36; agosto, 21; setembro, 33; outubro, 203; novembro, 46; dezembro, 25. A média de número de artigos com a palavra foi de 44.25 por mês; a moda foi 25 e a mediana entre 25 e 33.

${ }^{5}$ Em janeiro, a palavra aborto foi mencionada em 70 notícias; fevereiro, 21; março, 50; abril, 40; maio, 56; junho, 53; julho, 49; agosto, 43; setembro, 74; outubro, 583; novembro, 63; dezembro, 32.

${ }^{6}$ Disponível em: < http://www.observatoriodaimprensa.com.br/ news/view/a-manipulacao-do-aborto $>$ Acesso em: 30/11/2011. 
mudam de posição sobre aborto e casamento gay". ${ }^{7}$ Entretanto, não se identifica continuidade imediata dessa acusação da candidata Marina Silva (PV) na cobertura de $O$ Globo sobre a campanha eleitoral. Nesse mesmo dia, $1^{\circ}$ de setembro, a notícia da Folha.com relacionando aborto e campanha eleitoral comenta sobre a visita do candidato Plínio Arruda (PSOL) à Universidade Federal do Rio de Janeiro (UFRJ), onde mencionou o tema com alunos. Ele se disse favorável à legalização, sem "liberar geral”. ${ }^{8}$ No dia seguinte, uma notícia sobre entrevista de Marina Silva (PV) ao programa "Jornal da Globo" menciona sua proposta de plebiscito sobre o tema. A candidata critica o "debate raivoso". ${ }^{9}$

O jornal O Globo faz uma sequência de entrevistas com candidatos e todos são indagados sobre o aborto: Plínio de Arruda Sampaio (PSOL) em 5 de setembro, ${ }^{10}$ e Marina Silva (PV) em 9 de setembro, ${ }^{11}$ em disputa pela presidência, e dos postulantes ao senado, Waguinho do Partido Trabalhista do Brasil (PT do B) em 20 de setembro ${ }^{12} \mathrm{e}$ Marcelo Crivella do Partido Republicano Brasilei-

Sérgio Roxo. Marina diz que adversários mudam de posição sobre aborto e casamento gay. O Globo, 01 set 2010. Publicada em 01/09/2010 às 13h23. Disponível em: < http://oglobo.globo.com/pais/eleicoes2010/mat/ 2010/09/01/marina-diz-que-adversarios-mudam-deposicao-sobre-aborto-casamento-gay-917526086.asp $>$. Acesso em: 17/02/2011.

${ }^{8}$ Hudson Corrêa. Plínio de Arruda prevê caos no país com a sua eleição. Folha.com, 01 set 2010 - 10h51. Disponível em <http://www1.folha.uol.com.br/poder/792188plinio-de-arruda-preve-caos-no-pais-com-suaeleicao.shtml> Acesso em: 26/05/2011.

${ }^{9}$ Marina afirma quenão daria ‘audiência' a Ahmadinejad. Folha.com, 2/09/2010 - 1h00. Disponível em: <http://www1.folha. uol.com.br/poder/792706-marina-afirma-que-nao-dariaaudiencia-a-ahmadinejad.shtml> Acesso em: 26/05/2011.

${ }^{10}$ Tatiana Farah. Em entrevista ao GLOBO, Plínio de Arruda ataca 'políticas capitalistas', além de Dilma, Serra e Marina. O Globo, Publicada em 05/09/2010 às 23h48m. Disponível em: < http://oglobo.globo.com/pais/ eleicoes2010/mat/ 2010/09/05/em-entrevista-ao-globo-plinio-de-arruda-ataca-politicas-capitalistas-alem-de-dilma-serra-marina917563215.asp>Acesso em: 17/02/2011.

11 'Lula não deu satisfação ao povo, apenas defendeu sua candidata', diz Marina sobre escândalo da Receita. O Globo. Publicada em 09/09/2010 às 13h12. Disponível em: <http://oglobo.globo.com/pais/eleicoes2010/mat/ 2010/ 09/09/lula-nao-deu-satisfacao-ao-povo-apenas-defendeu-sua-candidata-diz-marina-sobre-escandalo-da-receita-917588194.asp> Acesso em: 17/02/2011.

${ }^{12}$ Carter Anderson e Natanael Damasceno. Waguinho: 'Prioridade é aumentar a recuperação de drogados'. O Globo, publicada em 20/09/2010 às 16h11. Disponível em: <http://oglobo.globo.com/pais/eleicoes2010/mat/ 2010/ 09/20/waguinho-prioridade-aumentar-recuperacao-dedrogados-919580450.asp> Acesso em 17/02/2011. ro (PRB) em 21 de setembro. ${ }^{13}$ A Folha de S. Paulo apresenta, no mês de setembro, um número bem maior de entrevistas com candidatos, com menção à palavra-chave: Osmar Dias, governador do Paraná e candidato pelo PDT (1 de setembro); ${ }^{14}$ Beto Richa (PSDB), candidato ao governo do Paraná (2 de setembro); ${ }^{15}$ César Maia (DEM), candidato ao senado pelo RJ (28 de setembro); ${ }^{16}$ Aloysio Nunes (PSDB), candidato a senador por São Paulo (25 de setembro); ${ }^{17}$ Lindberg Faria (PT), candidato ao Senado $\mathrm{RJ} ;{ }^{18}$ Netinho de Paula (PCdoB) candidato ao Senado de SP (22 de setembro). ${ }^{19}$

A única matéria, na segunda dezena do mês, que menciona aborto, exceto pelas entrevistas aos políticos, é de Zuenir Ventura, importante articulista de O Globo. Ventura aponta o "fator Marina" como a grande novidade da eleição presidencial: após elogiar sua postura ética e descrever sua trajetória de vida, o autor faz uma ressalva quanto à “[...] contradição entre suas posições políticas avançadas e o conservadorismo de seus princípios evangélicos contra o aborto, o casamento gay e a regula-

${ }^{13}$ Carter Anderson e Elenilce Bottari. Crivella defende parceria com Lula e diz que, se reeleito, quer fazer CPI sobre fronteiras para coibir tráfico de drogas. O Globo, publicada em 21/09/2010 às 23h21. Disponível em:<http:// oglobo.globo.com/pais/eleicoes2010/mat/2010/09/21/ crivella-defende-parceria-com-lula-diz-que-se-reeleitoquer-fazer-cpi-sobre-fronteiras-para-coibir-trafico-dedrogas-921047766.asp>Acesso em: 17/02/2011.

${ }^{14}$ Em sabatina, Osmar Dias diz que metrô não é solução indicada para transporte no PR. Folha.com, 01/09/2010 13h00. Disponível em: <http://www1.folha.uol.com.br/ po...ada-para-transporte-no-pr.shtml>. Acesso em: 17/ $02 / 2011$.

${ }^{15}$ Em sabatina, Richa promete, se eleito, modernizar e ampliar Porto de Paranaguá. Folha.com. 02/09/2010 12h55. Disponível em: <http://www1.folha.uol.com.br/ po...mpliar-porto-de-paranagua.shtml. Acesso em: 17/ $02 / 2011$.

${ }^{16}$ Italo Nogueira, Plínio Fraga. Maia se diz candidato para evitar 'kit-chavista' do PT. Folha.com, 28/09/2010 - 10 h56. Disponível em: <http://www1.folha.uol.com.br/po...evitarkit-chavista-do-pt.shtml> Acesso em: 17/02/2011.

17 Evandro Spinelli. Aloysio Nunes lamenta saída de Quércia e diz fazer campanha sozinho ao Senado. Folha.com, 25/09/2010 - 07h02. Disponível em: <http:/ /www1.folha.uol.com.br/po...ampanha-sozinho-aosenado.shtml $>$. Acesso em: 17/02/2011.

18 Italo Nogueira, Plínio Fraga. Lindberg prega ‘distensionamento político' com o PSDB. Folha.com, 24/ 09/2010 - 10h46. Disponível em: <http:// www1.folha.uol.com.br/po...mento-politico-com-opsdb.shtml> Acesso em: 17/02/2011.

${ }^{19}$ Daniela Lima; Evandro Spinelli. 'Sou um cara que deu certo’, diz Netinho de Paula. Folha.com, 22/09/2010 - 07h45. Disponível em: < http://www1.folha.uol.com.br/po...ertodiz-netinho-de-paula.shtml > Acesso em: 17/02/2011. 
mentação das drogas" ${ }^{20}$

\section{O surgimento súbito do tema aborto como divisor de águas em período adiantado da campanha presidencial}

Somente em 22 de setembro, exceto pelas entrevistas aos candidatos citadas acima, o tema aborto aparecerá relacionado à campanha eleitoral em anúncio do debate promovido pela CNBB na Folha.com ${ }^{21}$ e, no dia seguinte, com a descrição do debate. Nele, Marina Silva (PV) defendeu a realização de um plebiscito sobre o tema, e Dilma Rousseff (PT), opondo-se ao plebiscito, disse que as alternativas legais eram suficientes. ${ }^{22}$ Ainda no dia 23 de setembro, ${ }^{23}$ foi noticiado que o Arcebispo de Belém, contrário à liberação do aborto, divulgou uma carta antipetista. Começa a aparecer, nesse momento, no material da grande imprensa aqui examinado, o registro da opinião do grupo mais conservador católico, que já havia começado a se manifestar no site da CNBB desde julho, com artigo do bispo de Guarulhos D. Luiz Gonzaga Bergonzini, que orientava os católicos a não votarem em candidato que "desrespeitasse a vida" e os "valores familiares" (apud Machado, 2012, p.35). Representando o mesmo espectro do catolicismo, foi publicado, em agosto, documento da Comissão Representativa dos Bispos do Regional Sul 1 da CNBB que, após listar deliberações do PT no

${ }^{20}$ Ventura, Zuenir. O fator Marina. O Globo, 15 set 2010. Disponível em: <http://oglobo.globo.com/pais/moreno/ posts/2010/09/15/o-fator-marina-324525.asp > Acesso em: $19 / 02 / 2011$.

${ }^{21}$ Larissa Guimarães; Márcio Falcão. Regras para debate da CNBB impedem confronto entre presidenciáveis Folha.com, 22/09/2010 - 12h58. Disponível em: < http:/ /www1.folha.uol.com.br/poder/802903-regras-para-debat e - d a - c n b b - i m p ed e m - c o n f r on t o - e n t r e presidenciaveis.shtml> Acesso em 26/05/2011.

${ }^{22}$ Presidenciáveis evitam temas espinhosos em debate e focam em propostas. Folha.com, 23/09/2010 - 22h57. Disponível em: < http://www1.folha.uol.com.br/poder/ 803952-presidenciaveis-evitam-temas-espinhosos-emdebate-e-focam-em-propostas.shtml> Acesso em: 26/ $05 / 2011$.

${ }^{23}$ Sílvia Freire. Contra a liberação do aborto, arcebispo de Belém divulga carta antipetista. Folha.com, 23/09/2010 18h15. Disponível em: <http://www1.folha.uol.com.br/ poder/803726-contra-a-liberacao-do-aborto-arcebispode-belem-divulga-carta-antipetista.shtml > . Acesso em: $26 / 05 / 2011$. campo dos direitos reprodutivos e da interrupção da gravidez, recomendava o voto em candidatos e partidos contrários à descriminalização do aborto (Machado, 2012).

No final de setembro, inicia-se a abordagem da grande imprensa sobre as mudanças recentes na preferência dos eleitores, poucos dias antes do segundo turno: Merval Pereira, colunista de O Globo, comenta a diminuição da diferença entre os candidatos, com a ascensão de Marina Silva (PV) e de José Serra (PSDB). Aponta como um dos fatores para a queda de Dilma Rousseff (PT) “[...] o voto dos evangélicos, que estão sendo orientados em diversos pontos do país a não votar em Dilma porque o PT seria favorável ao aborto". ${ }^{24} \mathrm{O}$ modo como se deu essa virada do voto de evangélicos é exemplificado na coluna "Caiu na rede", que comenta tendências da Internet, com a notícia: "Pastor prega voto contra o PT e vira fenômeno no Youtube". A nota se refere ao grande número de acessos de um vídeo com pregação do pastor Paschoal Piragine Júnior, da Primeira Igreja Batista de Curitiba, sobre o empenho de líderes cristãos em impedir a eleição de parlamentares comprometidos com a legalização do aborto ou da união de pessoas do mesmo sexo, identificados com PT, acusado de ter expulsado deputados que se manifestaram contra o aborto. ${ }^{25}$

Na versão impressa de $O$ Globo, a primeira notícia (24 de setembro) que destaca o tema, inclusive no título ("Aborto: Marina e Dilma confrontadas em debate"), relata debate organizado pela CNBB na Universidade Católica de Brasília. Nele, Marina Silva (PV) teria defendido um plebiscito sobre o assunto, não julgando impedimento sua posição pessoal divergente da linha partidária do PV, e dizendo-se contra o discurso da conveniência. Dilma não julgava necessário ampliar os casos já permi-

${ }^{24}$ Pereira, Merval. Razões. O Globo, 24 set 2010. Disponível em: <http://oglobo.globo.com/pais/ noblat/posts/ 2010/09/24/razoes-327133.asp > Acesso em: 19/02/2011

${ }^{25}$ Adriana Vasconcelos. Pastor prega voto contra o PT e vira fenômeno no Youtube. O Globo, Caiu na rede, 22/ 09/2010, 12h30. Disponível em: <http:// oglobo.globo.com/pais/moreno/diarioreporter/posts/ 2010/09/22/caiu-na-rede-pastor-prega-voto-contra-ptvira-fenomeno-no-youtube-326549.asp > Acesso em 17/
ving $02 / 2010$. 
tidos de aborto legal, manifestou-se a favor da defesa da vida e, pessoalmente, não favorável ao aborto, pretendendo tratar como problema de saúde pública o atendimento às mulheres vítimas. ${ }^{26}$

O único artigo de opinião sobre o tema nesse mês, em O Globo, é da presidente do Conselho Regional de Serviço Social (RJ) e professora da Escola de Serviço Social da UFRJ, Fátima da Silva Grave Ortiz. ${ }^{27} \mathrm{Em}$ "Um assunto delicado", questiona a criminalização do aborto, propõe abordá-lo como problema de saúde pública e denuncia as consequências do aborto clandestino e inseguro (mortes e sequelas). A autora advoga que a mulher deveria ter o direito de decidir e fala da importância do "Estado laico" para a criação de um marco legal e a criação de serviços para sua realização.

Na versão on line de O Globo.com, destacase a nota na coluna Blog do Noblat de 28 de setembro, intitulada "Parte do voto religioso começa a abandonar Dilma", que comenta a migração de votos de evangélicos da Baixada Fluminense de Dilma Rousseff (PT) para Marina Silva (PV). A nota relata sobre um padre que exibiu em missa o vídeo do pastor mencionado acima, que prega contra candidatos favoráveis ao aborto, bem como a promoção pela Igreja Católica da "Marcha para Jesus e em favor da vida" em Recife, quando se distribuiu panfleto acusando Dilma Rousseff (PT) de ser favorável ao aborto. ${ }^{28}$

Folha.com retrata a mesma tendência já vista em $O$ Globo às vésperas do primeiro turno: o posicionamento público de lideranças religiosas quanto aos candidatos, tendo por referência sua posição contrária ou favorável ao aborto. Em 28 de setembro, o pastor Silas Malafaia (da Igreja Assembleia de Deus Vitória em Cristo) acusa Marina

${ }^{26}$ Lima, Maria; Vasconcelos, Adriana; Gois, Chico de e Jungblut, Cristiane. Aborto: Marina e Dilma confrontadas em debate. O Globo, 24 set. 2010, O País, p.10.

${ }^{27}$ Ortiz, Fátima da Silva Grave. Um assunto delicado. O Globo, 27 set 2010, Opinião, p. 7. A autora erra um dos permissivos para o aborto, citando "comprovada existência de anomalia fetal” no lugar de risco de vida para a mãe.

${ }^{28}$ Noblat, Ricardo. Parte do voto religioso começa a abandonar Dilma. O Globo, Blog do Noblat, 28/09/2010, enviado em 21h55. Disponível em: <http:// oglobo.globo.com/pais/noblat/posts/2010/09/28/partedo-voto-religios o-comeca-abandonar-dilma328314.asp> Acesso em: 17/02/2011
Silva (PV) "de 'dissimular' suas ideias sobre a liberação do aborto e da maconha”, ao propor o plebiscito, e anuncia apoio a José Serra (PSDB). A matéria assinala a mudança de posição do pastor que, antes, havia declarado apoio a Marina Silva (PV). ${ }^{29}$ Machado (2012) assinala que Malafaia falou nos programas do candidato José Serra (PSDB), no Horário Político Eleitoral Gratuito, e distribuiu gratuitamente DVDs em sua igreja com a declaração de voto.

Uma reação de outra liderança evangélica vira notícia no dia seguinte: "Edir Macedo divulga carta em defesa de Dilma”. Em notícia obtida do Valor On Line, o plantão da edição eletrônica de $O$ Globo apresenta carta em que o bispo da Igreja Universal do Reino de Deus (IURD) denuncia que a candidata é vítima de "boatos" (sic) quanto a ser favorável ao aborto e ao casamento de pessoas do mesmo sexo. ${ }^{30}$ Também a Folha.com noticia a carta de Edir Macedo, bispo da IURD, em apoio a Dilma Rousseff (PT), dizendo ser ela vítima de mentiras. ${ }^{31}$ Segundo Machado (2012), dentre os líderes religiosos, Macedo teve a posição mais ousada na defesa da candidatura petista e foi um aliado político importante junto às camadas populares.

Folha.com relata a movimentação do PT na campanha presidencial, com respeito à queda de intenção de votos dos religiosos, por conta de posições favoráveis à descriminalização do aborto. Uma notícia, veiculada em 29 de setembro, informa a gravação de inserções comerciais pelo presidente Lula "[...] contra a onda de boatos que circula entre religiosos católicos e evangélicos $[\ldots]^{{ }^{32} \mathrm{e}}$

${ }^{29}$ Bernardo Mello Franco; Catia Seabra. Líder evangélico ataca Marina e anuncia apoio a Serra. Folha.com, 28/09/ $2010-08 \mathrm{~h} 47$. Disponível em: <http:// www1.folha.uol.com.br/poder/805644-lider-evangelicoataca-marina-e-anuncia-apoio-a-serra.shtml > Acesso em: 26/05/2011.

${ }^{30}$ Taquari, Fernando. Edir Macedo divulga carta em defesa de Dilma. O Globo, 29/09/2010 às 20h23. Disponível em: <http://oglobo.globo.com/pais/mat/2010/09/29/edirmacedo-divulga-carta-em-defes a-de-dilma922662192.asp>. Acesso em: 17/02/2011.

${ }^{31}$ Edir Macedo divulga carta em apoio a candidatura de Dilma. Folha.com, 29/09/2010, às 18h23. Disponível em: <http://www1.folha.uol.com.br/poder/806780-edirmacedo-divulga-carta-em-apoio-a-candidatura-dedilma.shtml> Acesso em: 26/05/2011.

${ }^{32}$ Valdo Cruz; Ranier Bragon; Márcio Falcão. Risco de $2^{\circ}$ turno leva Dilma a acionar Lula. Folha.com, 29/09/2010, às 08h29. Disponível em: http://www1.folha.uol. com.br/ poder/806219-risco-de-2-turno-leva-dilma-a-acionarlula.shtml. Acesso em: 26/05/2011. 
outra, publicada mais tarde, já descreve o vídeo. ${ }^{33}$ No mesmo dia, o jornal noticia reunião de Dilma com evangélicos e católicos para desmentir boatos. ${ }^{34}$ Estavam presentes, na reunião, o deputado federal Gabriel Chalita (PSB) e o Pastor Manoel Ferreira, "coordenador do segmento evangélico da campanha dilmista"; o primeiro é católico, da Renovação Carismática, e o segundo é da Assembleia de Deus, pertencimento não informado na matéria. Ainda em 29 de setembro, outra notícia mostra a candidata Marina Silva (PV) acusando Dilma Rousseff (PT) de mudar de discurso sobre aborto para ganhar votos. ${ }^{35}$

No último dia de setembro, o tema aborto, nas eleições, vira matéria de primeira página em $O$ Globo: "Aborto opõe Marina a Dilma e esquenta guerra de candidatas: petista muda de posição e verde a acusa de agir por conveniência eleitoral". A matéria continua em página interna: "Marina, Dilma e o aborto: candidata do PV acusa a petista de fazer discurso de conveniência para agradar ao eleitor" é o título de outra matéria. O título de outra notícia mostra a candidata petista rebatendo a proposta de Marina Silva (PV) e menciona as acusações na Internet: "Dilma: 'acho que plebiscito divide o país': na reta final, petista, com ajuda de Lula, tenta antídoto contra guerrilha virtual". O jornal também mostra a declaração de José Serra (PSDB) contrária ao aborto, insinuando duplicidade de Dilma Rousseff (PT): "Serra: 'eu não tenho duas caras"” ${ }^{36}$ A coluna de Merval Pereira, no mesmo

${ }^{33}$ Valdo Cruz; Ranier Bragon. Em vídeo, Lula rebate boatos contra Dilma sobre religião. Folha.com, 29/09/2010, às 16h17. Disponível em: <http:// www1.folha.uol.com.br/poder/806621-em-video-lularebate-boatos-contra-dilma-sobre-religiao.shtml> . Acesso em: $26 / 05 / 2011$.

${ }^{34}$ Márcio Falcão. Dilma faz reunião com evangélicos e católicos para desmentir boatos. Folha.com, 29/09/2010, às 15h23. Disponível em: <http:// www1.folha.uol.com.br/poder/806590-dilma-fazreuniao-com-evangelicos-e-catolicos-para-desmentirboatos.shtml>. Acesso em: 26/05/2011.

${ }^{35}$ Bernardo Mello Franco. Marina acusa Dilma de mudar discurso sobre aborto para ganhar votos. Folha.com, 29/ 09/2010, às 19h08. Disponível em: <http:// www1.folha.uol.com.br/poder/806807-marina-acusadilma-de-mudar-discurso-sobre-aborto-para-ganharvotos.shtml>. Acesso em: 26/05/2011.

${ }^{36}$ Aborto opõe Marina a Dilma e esquenta guerra de candidatas: petista muda de posição e verde a acusa de agir por conveniência eleitoral. O Globo, 30 set p.1, 2010. Celestino, Miguel. Marina, Dilma e o aborto: candidata dia, aborda o esforço da candidata do PT para evitar o desgaste com o eleitorado por meio de declarações desmentindo ser favorável ao aborto e da reunião com lideranças católicas e evangélicas. ${ }^{37}$

Embora a grande imprensa não tenha apontado, desde o início, houve divisão dos evangélicos na preferência eleitoral. No tocanteà Assembleia de Deus, Machado (2012) identificou o apoio de primeira hora do Pastor Manuel Ferreira (Convenção das Igrejas Assembleias de Deus de Madureira) à candidatura de Dilma Rousseff (PT); o apoio do Pastor da Assembleia de Deus, Sóstenes Apolos da Silva, a Marina Silva (PV); e do Pastor José Wellington Bezerra, presidente da Convenção Geral das Assembleias de Deus do Brasil, ao candidato José Serra do PSDB. Bezerra acionou os veículos de comunicação de seu grupo contra a candidatura do PT.

Quanto ao número de notícias com a palavra aborto veiculadas na grande imprensa, percebe-se uma variação com uma curva ascendente nos últimos dez dias de setembro. O quadro, às vésperas do primeiro turno, fica mais embaralhado. Vários analistas já identificam a migração de votos religiosos, explicados pela associação da candidata Dilma Rousseff (PT) ao aborto. Lideranças religiosas se manifestam publicamente: 0 vídeo anti-PT foi divulgado pelo pastor batista ainda em agosto; Silas Malafaia anunciou apoio a José Serra (PSDB); um arcebispo e um padre católico combatem o voto em candidatos do PT, por serem favoráveis ao aborto; $\mathrm{e}$ o Bispo Edir Macedo, da Igreja Universal, rebate os boatos e defende a candidata do PT. Como reação, o PT grava programas eleitorais contra os boatos. Considerando os principais candidatos, Marina Silva (PV) e José Serra (PSDB) acusam Dilma Rousseff (PT) de duplicidade de posições. Encerra-se o mês de setembro, às vésperas do primeiro turno, e o aborto se torna um divisor de águas e de candidatos.

do PV acusa a petista de fazer discurso de conveniência para agradar ao eleitor; Serra: 'eu não tenho duas caras'. O Globo, 30 set p.3, 2010. Camarotti, Gerson. Dilma: 'acho que plebiscito divide o país: na reta final, petista, com ajuda de Lula, tenta antídoto contra guerrilha virtual. O Globo, 30 set p.3, 2010.

${ }^{37}$ Pereira, Merval. Diferenças e tendências. O Globo, 30 set p.4, 2010. 


\section{A COBERTURA DA IMPRENSA EM OUTUBRO ${ }^{38}$}

Em outubro, em função do segundo turno, as notícias ficam mais centradas no embate entre Dilma Rousseff (PT) e José Serra (PSDB). O enfoque nos evangélicos vai durar até a obtenção de uma carta compromisso de Dilma. Aumenta o protagonismo católico na associação da candidata do PT ao aborto. E o aborto em si, como é retratado na grande imprensa?

\section{A conclusão do $1^{\circ}$ turno: a palavra do Cardeal}

No sábado, 2 de outubro, véspera do primeiro turno, foi publicada a coluna semanal de D. Eugênio Sales, cardeal-arcebispo emérito da Arquidiocese do Rio de Janeiro, com o título "O voto católico". O cardeal recomenda que o pleito seja "avaliado segundo os critérios do Evangelho" e considera o "voto consciente" um dever. Segundo o cardeal:

O verdadeiro compromisso político inclui a preservação da vida em todas as suas formas e etapas, desde a concepção no seio materno até a proteção e o apoio na velhice: $\mathrm{o}$ aborto, por exemplo, deve ser claramente condenado como oposto à Lei divina e à fundamental dignidade da própria criatura racional. Um candidato que se

${ }^{38}$ Desta seção em diante, este artigo vai se pautar pela versão impressa do jornal O Globo, complementada pela versão impressa de outros jornais e revistas de grande circulação que abordaram o tema. Os outros veículos foram localizados principalmente através de matérias de primeira página ou de capa.

${ }^{39}$ Sales, D. Eugênio. O voto católico. O Globo, 2 out. 2010. Opinião, p. 7.

\section{$O$ peso do voto religioso no $1^{\circ}$ turno e a posi- ção de Dilma Rousseff e do PT sobre aborto}

Já no dia 5 de outubro, aparece um balanço do resultado realizado pelos próprios partidos e suas perspectivas para o segundo turno da eleição presidencial. Crescem as referências ao voto religioso, já assinaladas no final de setembro, e o aborto vira tema de pauta, o que se explicita no título da matéria de primeira página: "Dilma fará ofensiva religiosa para atrair voto conservador". A manchete comenta o reconhecimento de Dilma Rousseff (PT) e dos aliados que teriam demorado a agir contra os "boatos" na Internet que afirmavam ser ela favorável ao aborto e contra a vida. ${ }^{40}$ No mesmo dia, é publicada notícia avaliando a perspectiva dos líderes e políticos evangélicos aliados da candidata do PT, intitulada: "Para evangélicos, PT subestimou boatos: líderes acreditam que resposta mais rápida para acusações feitas a Dilma garantiria 'pontinhos que faltaram"”. Na matéria, são mencionados o Pastor Manoel Ferreira, "presidente da Assembleia de Deus de Madureira" (sic) e o bispo Rodovalho, da Igreja Sara Nossa Terra, apoiadores da candidata do PT desde o primeiro turno. ${ }^{41}$ Outra matéria chama de "cruzada" a ofensiva católica e evangélica contra o PT e Dilma Rousseff devido à posição favorável à legalização do aborto, comentando tanto o documento da Regional Sul 1 da CNBB como o já citado vídeo do culto batista em que o pastor pede para não se votar em petistas. ${ }^{42}$ No dia seguinte, matéria de primeira página em $O$ Globo de título "PT já puniu quem é contra o aborto" apresenta a versão do deputado federal Luiz Bassuma sobre a suspensão que motivou sua saída do $\mathrm{PT}$ para o $\mathrm{PV}^{43}$ sendo Bassuma entrevistado pelo jornal O Estado de

40 Dilma fará ofensiva religiosa para atrair voto conservador. O Globo, 5 out. 2010. p. 1.

${ }^{41}$ Otávio, Chico. Para evangélicos, PT subestimou boatos: líderes acreditam que reposta mais rápida para acusações feitas a Dilma garantiria 'pontinhos que faltaram'. O Globo, 5 out. 2010. O País, p. 9.

${ }^{42}$ Suwwan, Leila. Ofensiva contra o PT: católicos e evangélicos se opõem a Dilma. O Globo, 5 out. 2010. O País, p. 9.

${ }^{43}$ PT já puniu quem é contra aborto. O Globo, 6 out. 2010, p.1. Camarotti, Gerson. PT já puniu deputado contrário ao aborto. Hoje no PV, Luiz Bassuma diz que mudança de posição de Dilma Rousseff sobre o tema é 
S. Paulo no dia seguinte sobre o tema. ${ }^{44}$ Outra matéria em O Globo (6 de outubro) reporta documentos do PT defendendo a legalização do aborto, bem como declarações mais antigas de Dilma Rousseff nesse sentido. ${ }^{45}$ "Sob pressão, Dilma fala em 'valorização da vida': objetivo é recuperar votos após polêmica do aborto" é a manchete de primeira página de $O$ Estado de $S$. Paulo em 6 de outubro. ${ }^{46}$ Na página interna, a matéria continua relatando as mudanças na propaganda eleitoral na TV: "Na TV, Dilma terá novo tom sobre o aborto: temática da reestreia da propaganda eleitoral faz parte da estratégia para recuperar os votos perdidos após polêmica”. ${ }^{47}$ Ainda no dia 6 de outubro, notícia em $O$ Estado de S. Paulo comenta o manifesto do "Movimento Nacional da Cidadania pela Vida (Brasil sem Aborto) contra "candidatos que manifestaram publicamente, com palavras e ações, posicionamento pela descriminalização do aborto". Descreve-se a composição da entidade por representantes da CNBB, da Federação Espírita e de grupos evangélicos. ${ }^{48}$ Outras matérias no OESP abordam a divergência de bispos da CNBB para tratar a candidata Dilma Rousseff: o bispo de Guarulhos D. Luiz Gonzaga Bergonzini, que vetou o nome da candidata do PT por aprovar o aborto, e o bispo de Jales, D. Luiz Demétrio Valentini, que considera a acusação caluniosa. ${ }^{49}$ Também se reporta à posição de políticos evangélicos aliados de Dilma

casuísmo eleitoral. O Globo, 6 out. 2010, O País, p. 9.

${ }^{44}$ Moraes, Marcelo de. 'Se mentir sobre o aborto, ela vai dar um tiro no próprio pé’. O Estado de S. Paulo, 6 out. 2010, Nacional, p. A9.

${ }^{45}$ Lima, Maria. No papel, PT defendeu legalização. Após polêmica, aborto foi retirado no Plano Nacional de Direitos Humanos. O Globo, 6 out. 2010, O País, p. 9.

${ }^{46}$ Sob pressão, Dilma fala em 'valorização da vida': objetivo é recuperar votos após polêmica do aborto. O Estado de S. Paulo, 6 out. 2010, p. 1.

${ }^{47}$ Rosa, Vera; Andrade, Renato. Na TV, Dilma terá novo tom sobre o aborto: temática da reestréia da propaganda eleitoral faz parte da estratégia para recuperar os votos perdidos após polêmica. O Estado de S. Paulo, 6 out. 2010, Nacional, p. A8.

${ }^{48}$ Maia, Lucas de Abreu. Manifesto critica Dilma por posição sobre aborto. Movimento ataca petista por declarações ‘oportunistas, ambíguas e eleitoreiras'. O Estado de S. Paulo, 6 out. 2010, Nacional, p. A9.

${ }^{49}$ Mayrink, José Maria. Bispos divergem sobre como tratar a candidata: o de Guarulhos sugere Serra dizendo 'de dois males o menor'. O de Jales fala em 'calúnias' e a CNBB fica na doutrina. O Estado de S. Paulo, 6 out. 2010, Nacional, p. A9.
Rousseff, que sugerem à candidata expor posição contrária ao aborto como estratégia de campanha para o segundo turno: o deputado Manoel Ferreira (PR-RJ), coordenador evangélico da campanha, e o deputado Robson Rodovalho, bispo da Igreja Sara Nossa Terra ${ }^{50}$ Na coluna "Caiu na rede" do jornal $O$ Globo de 06 de outubro, o assunto aborto consta na lista do "Trending Topics do Twitter", assinalando sua importância no resultado de votação do primeiro turno e sua influência no segundo. ${ }^{51}$ Nesse primeiro momento, após o primeiro turno, alguns aspectos se repetem: a rememoração de posições de Dilma Rousseff e do PT favoráveis à legalização do aborto; a avaliação de que o voto religioso foi fundamental para ela não ter vencido no primeiro turno e o posicionamento de lideranças religiosas e do movimento antiaborto. Cabe destacar aqui que os religiosos não aparecem com posição unitária: há destaque para as lideranças evangélicas apoiadoras da referida candidata, lamentando a reação tardia dela mesma e do PT contra as acusações acerca do aborto; a divisão entre bispos da CNBB sobre a candidata do PT; a articulação do movimento antiaborto contra candidatos que se posicionaram a favor da descriminalização, movimento composto por católicos, evangélicos e espíritas. Acerca das lideranças religiosas, quase sempre os mesmos nomes são referidos.

\section{A mudança de estratégia de campanha do PT: as críticas}

A mudança de estratégia da campanha é a tônica após a avaliação do resultado das eleições: "Agora, programa do PT será contra aborto: Campanha de Dilma volta atrás e não vai mais esperar fim do segundo turno para divulgar seu plano de governo". A notícia adianta a decisão de comunicar ao público que a candidata, se eleita, não de-

${ }^{50}$ Leal, Luciana Nunes. Para evangélico, saída é a petista condenar o aborto. Pastor do Rio pede que a candidata faça 'manifestações claras contra o aborto e de valorização da vida'. O Estado de S. Paulo, 6 out. 2010, Nacional, p. A9.

${ }^{51}$ Vasconcelos, Adriana. Aborto em pauta. O Globo, 6 out. 2010, Caiu na rede, p. 4. 
fenderá temas polêmicos como o aborto e o casamento gay. ${ }^{52}$ No mesmo dia, também se menciona o candidato José Serra em outra notícia: "Serra se confunde ao falar sobre aborto: 'Nunca disse que sou contra, porque sou a favor', disse tucano para depois se corrigir; ele afirmou que o chamam de 'atrasado"'. O candidato critica o PT por retirar esse ponto do programa e sua adversária por esconder suas opiniões. ${ }^{53}$ Nesse mesmo dia, surge um foco diferente, que aborda a ausência de direitos das mulheres na pauta eleitoral, obscurecida pela ênfase no aborto: "Aborto ofusca debate sobre questões femininas", na $1^{a}$ página. A reportagem traz declarações da atriz Claudia Jimenez, duas lideranças feministas, Gilda Cabral do Centro Feminista de Estudos e Assessoria (Cfemea) e a escritora Rose Marie Muraro, Lucinha Araújo, presidente da Sociedade Viva Cazuza (ONG de assistência às crianças portadoras do HIV), e duas especialistas das ciências sociais, a cientista política Fernanda Feitosa e Lena Levinas (professora de políticas públicas do Instituto de Economia da UFRJ). A última afirma que o debate sobre o aborto é ideológico. ${ }^{54}$

O surgimento súbito do tema aborto como divisor de águas em período adiantado da campanha presidencial também é assunto tanto do articulista Luiz Garcia, como do editorial de O Globo no dia 8 de outubro. Garcia comenta a antecipação do programa de governo do PT, cujo objetivo seria avisar que a candidata não pretende atacar temas "polêmicos" como o aborto ou o casamento de homossexuais. Reconhece a importância do tratamento do tema pelo Estado, com o alerta para não ocupar o espaço de outros temas importantes para o "eleitorado feminino" ${ }^{55} \mathrm{O}$ editorial "Fundamentalismo nas

${ }^{52}$ Lima, Maria. Agora, programa do PT será contra aborto: Campanha de Dilma volta atrás e não vai mais esperar fim do segundo turno para divulgar seu plano de governo. O Globo, 7 out. 2010, O País, p. 10.

${ }^{53}$ Jungblut, Cristiane; Souza, André. Serra se confunde ao falar sobre aborto: 'Nunca disse que sou contra, porque sou a favor', disse tucano para depois se corrigir; ele afirmou que o chamam de 'atrasado'. O Globo, 7 out. 2010, O País, p.11.

${ }^{54}$ Aborto ofusca debate sobre questões femininas. O Globo, 7 out. 2010, p. 1. Duarte, Alessandra; Victor, Dulio. Aborto ofusca debate sobre mulheres: Temas como a falta de creches e ingresso no mercado de trabalho estão fora da pauta eleitoral. O Globo, 7 out. 2010, O País, p. 14.

${ }^{55}$ Garcia, Luiz. A dívida com elas. O Globo, 8 out. 2010, Opinião, p. 7. eleições" comenta a "mobilização quase subterrânea de grupos religiosos antiaborto" que permitiu o segundo turno, com migração de votos de Dilma Rousseff para Marina Silva. ${ }^{56} \mathrm{O}$ texto também ironiza a mudança de posição de Dilma em contraste com depoimentos anteriores à campanha, critica grupos conservadores contrários a qualquer tipo de aborto, reconhecendo seu caráter de problema de saúde pública e elogia a edição da norma técnica do SUS por Serra, então ministro da saúde. Nesse mesmo dia, mencionam o tema a manchete de primeira página "Votos de fé" e as matérias "Dilma visita capela e fala contra aborto", "Vice de Dilma busca apoio de Garotinho", "PT reage à agenda negativa", "Uma central de defesa no site: Campanha do PT agora nega posição pró-aborto e pede que militância denuncie calúnias". ${ }^{57}$ Todas essas matérias abordam a reação da candidata e do partido em desmentir posição favorável ao aborto, com Dilma Rousseff assumindo atitudes religiosas e favoráveis à vida, além da articulação principalmente com lideranças evangélicas. São citados como participantes o Senador Marcelo Crivella (PR) da Igreja Universal do Reino de Deus e Manoel Ferreira da Assembleia de Deus, além de contatos com a Igreja Mundial do Poder de Deus, a Assembleia de Deus dos Últimos Dias e grupos ligados ao deputado estadual Edino Fonseca (PR). Uma notícia relata a organização dos adversários para explorar o revés: "Índio pede a pastores discurso anti-Dilma: vice de Serra recomendou a associação de petista a ideias condenadas pela Igreja” ${ }^{58}$ A notícia não menciona nome de lideranças e apenas cita igrejas presentes: Assembleia de Deus,

${ }^{56}$ Opinião. Fundamentalismo nas eleições. O Globo, 8 out. 2010, Opinião, p. 6.

${ }^{57}$ Votos de fé. O Globo, 8 out. 2010, p. 1. Herdy, Thiago; Galdo, Rafael; Remigio, Marcelo. Dilma visita capela e fala contra aborto. O Globo, 8 out. 2010, O País, p. 12 Braga, Isabel; Jungblut, Cristiane; Lima, Maria. Vice de Dilma busca apoio de Garotinho. O Globo, 8 out. 2010, O País, p. 13. PT reage a 'agenda negativa'. O Globo, 8 out. 2010, O País, p. 13. Suwwan, Leila. Uma central de defesa no site: Campanha do PT agora nega posição próaborto e pede que militância denuncie calúnias. O Globo, 8 out. 2010, O País, p. 13.

58 Amorim, Sílvia; Freire, Flávio. Índio pede a pastores discurso anti-Dilma: vice de Serra recomendou a associação de petista a ideias condenadas pela Igreja. O Globo, 8 out. 2010, O País, p. 12. 
batista e Bola de Neve. A cobertura salienta também a convergência de estratégias dos candidatos: "Na volta à TV, Dilma e Serra 'defenderão a vida”. ${ }^{59}$ Duas matérias abordam a polêmica no contexto da Igreja Católica: "PT pede direito de resposta em TV católica"; "Arcebispo de São Paulo defende manifestação de bispos sobre eleições: Dom Odilo é contra punir religiosos que pedirem a fiéis para não votar no PT". ${ }^{60}$ Nesse momento, o PT e Dilma Rousseff buscam desmentir a posição favorável ao aborto e se articulam principalmente com lideranças evangélicas, algumas das quais parecem convidadas a aderir à campanha naquele momento. Com respeito aos agentes católicos, o conflito é mais explícito, com o PT pedindo direito de resposta e o arcebispo de São Paulo negando punição a quem pediu ao eleitor para não votar no PT.

\section{$O$ crescimento da referência à religião segun- do os especialistas}

Cresce a referência ao tema religioso tanto no contexto da propaganda na TV e no rádio como por especialistas convidados pelo jornal. A manchete na primeira página no dia 9 de outubro: "Candidatos invocam Deus e se atacam na propaganda da TV", com análise dos programas na matéria "Atrás de Deus e de Marina: na reestreia na TV, Serra e Dilma fazem discurso religioso e confrontam anos FH e Lula". ${ }^{61}$ A coluna de Merval Pereira apresenta uma avaliação do voto religioso com entrevista ao cientista político Cesar Romero Jacob (PUC-Rio), especialista em geografia eleitoral, que relativiza a importância desse voto como fator pre-

${ }^{59}$ Lima, Maria; Camarotti, Gerson; Amorim, Silvia. Na volta à TV, Dilma e Serra 'defenderão a vida'. O Globo, 8 out. 2010, O País, p. 14.

${ }^{60} \mathrm{PT}$ pede direito de resposta em TV católica. O Globo, 8 out. 2010, O País, p. 13. Arcebispo de São Paulo defende manifestação de bispos sobre eleições: Dom Odilo é contra punir religiosos que pedirem a fiéis para não votar no PT. O Globo, 8 out. 2010, O País, p. 14.

${ }^{61}$ Candidatos invocam Deus e se atacam na propaganda da TV. O Globo, 9 out. 2010, p. 1. Jungblut, Cristiane. Atrás de Deus e de Marina: na reestreia na TV, Serra e Dilma fazem discurso religioso e confrontam anos FH e Lula. O Globo, 9 out. 2010, O País, p. 3. ponderante para o segundo turno. ${ }^{62} \mathrm{~A}$ entrada do debate religioso na campanha presidencial é analisada por dois historiadores, o professor Marco Antônio Villa (UFSCAR) e Daniel Aarão Reis (UFF), na matéria: "Especialistas: tema religioso é exagerado: Para historiador, aumento do número de evangélicos criou tendência em que posição moral do candidato conta". ${ }^{63}$ Também é notícia a busca de votos evangélicos: "Crivella articula apoio evangélico a Dilma: bancada aliada defenderá a petista em temas como aborto e homofobia, alvos de boatos contra a candidata": a matéria não cita outros líderes religiosos engajados. ${ }^{64}$ A própria candidata volta a abordar o tema, dizendo defender "o verdadeiro projeto a favor da vida", contra o aborto, porque é "uma violência contra a mulher", mas considerando as mulheres "que cometem atos extremos e colocam a vida em risco" ${ }^{65} \mathrm{~A}$ imprensa retrata mais a articulação de evangélicos a favor de Dilma e especialistas fazem novo balanço da importância do voto religioso nas eleições.

\section{O aborto como problema de saúde pública: uma abordagem solitária de $O$ Globo}

A edição de domingo 10 de outubro teve como manchete o tema aborto, pela primeira vez discutido em termos de saúde pública, e não apenas no quadro eleitoral: "Aborto ilegal mata uma mulher a cada dois dias: Entre 1995 e 2007, SUS fez 3 milhões de curetagens no Brasil”. ${ }^{66}$ Várias matérias conjugadas abordam o tema a partir de dados estatísticos "Mortes em silêncio: tema de

${ }^{62}$ Pereira, Merval. Voto religioso reavaliado. O Globo, 9 out. 2010, p. 4.

${ }^{63}$ Victor, Dulio. Especialistas: tema religioso é exagerado. Para historiador, aumento do número de evangélicos criou tendência em que posição moral do candidato conta. O Globo, 9 out. 2010, O País, p. 18.

${ }^{64}$ Galdo, Rafael. Crivella articula apoio evangélico a Dilma: bancada aliada defenderá a petista em temas como aborto e homofobia, alvos de boatos contra a candidata. O Globo, 9 out. 2010, O País, p. 16.

${ }^{65} \mathrm{Em}$ dois eventos, Dilma volta a falar de aborto. O Globo, 9 out. 2010, O País, p. 16.

${ }^{66}$ Aborto ilegal mata uma mulher a cada dois dias: Entre 1995 e 2007, SUS fez 3 milhões de curetagens no Brasil. O Globo, 10 out. 2010, p. 1. 
última hora da campanha, aborto mata uma brasileira a cada dois dias" e "Uma em cada cinco brasileiras de até 40 anos já fez aborto: pesquisa aponta também que $48 \%$ das mulheres recorreram a abortivos", mas também com relatos das experiências das que fizeram aborto clandestino: "Depois, dá um vazio danado': sem recursos, mulheres recorrem a remédios e clínicas clandestinas". ${ }^{67}$ As fontes são dados do SUS e especialistas: as autoras da pesquisa "Aborto e saúde pública - 20 anos de aborto no Brasil" (a médica Marilena Corrêa) e da Pesquisa Nacional de Aborto (a antropóloga Debora Diniz), Paula Viana do Curumim (ONG feminista que pesquisou a mortalidade por aborto em cinco estados), o pesquisador Mario Monteiro (UERJ), a médica Greice Menezes do Instituto de Saúde Coletiva da UFRJ, Cristião Fernando Rosas, da Comissão de Nacional de Violência Sexual e Interrupção da Gravidez da FEBRASGO, e o médico Aníbal Faúndes da UNICAMP, que é consultor permanente da Organização Mundial de Saúde. Essa abordagem do aborto como problema de saúde pública é a única matéria localizada na comparação da cobertura jornalística sobre aborto no período dessas eleições, conforme revela a análise de Fontes (2012) em estudo quantitativo sobre o enquadramento do aborto na mídia impressa.

Outras notícias, veiculadas no dia 10 de outubro, vão retomar o tema do aborto na campanha: "Dilma diz que existe hipocrisia na discussão sobre o aborto: ao falar sobre o tema em visita a maternidade, petista cita a Bíblia" ${ }^{68} \mathrm{O}$ texto começa da seguinte forma: "[...] em mais uma atividade de campanha voltada para combater acusações de que é favorável ao aborto [...]", introdução que revela a tendência do jornal. A coluna de Elio Gaspari aborda as implicações do aborto no

\footnotetext{
${ }^{67}$ Benevides, Carolina; Farah, Tatiana. Mortes em silêncio: tema de última hora da campanha, aborto mata uma brasileira a cada dois dias. O Globo, 10 out. 2010, O País, p. 3. Uma em cada cinco brasileiras de até 40 anos já fez aborto: pesquisa aponta também que $48 \%$ das mulheres recorreram a abortivos. O Globo, 10 out. 2010, O País, p. 3. Depois, dá um vazio danado': Sem recursos, mulheres recorrem a remédios e clínicas clandestinas. O Globo, 10 out. 2010, O País, p. 3.

${ }^{68}$ Amorim, Sílvia. Dilma diz que existe hipocrisia na discussão sobre o aborto: Ao falar sobre o tema em visita a maternidade, petista cita a Bíblia. O Globo, 10 out. 2010, O País, p. 15.
}

Legislativo, no Judiciário e seu uso na campanha eleitoral de 2010 e no segundo turno da eleição de 1989 entre Collor e Lula. ${ }^{69}$ Acusa os tucanos de oportunismo, por abordarem o tema apenas na reta final da campanha e os petistas por mudarem de opinião. O tema é usado para "satanizar adversários políticos".

\section{O primeiro debate do segundo turno}

No dia 11 de outubro, o destaque, na primeira página, vai para o primeiro debate entre os candidatos no segundo turno: "Dilma muda estratégia e parte para o ataque direto a Serra. No primeiro debate do segundo turno, um duelo sobre aborto e privatização".$^{70}$ Há acusação mútua dos candidatos sobre mudar de posição. Dilma Rousseff acusa José Serra de campanha de difamação e exemplifica com a acusação de Monica Serra, esposa do candidato, de que Dilma seria "a favor da morte de criancinhas" conforme relato da Folha.com. ${ }^{71}$ No dia 12 de outubro, pela primeira vez, o tema aborto não é citado na primeira página de $O$ Globo desde o início do segundo turno. Destaca-se o editorial de $O$ Globo, que aborda o planejamento familiar como tópico que deveria preceder a discussão sobre necessidade ou não de legalização do aborto. ${ }^{72}$ É relevante também a matéria sobre o vídeo gravado pelo arcebispo metropolitano da Paraíba: "Arcebispo ataca Dilma e PT na internet: Dom Aldo Pagotto diz que petista e partido se comprometeram com a 'cultura da morte'; religioso faz críticas a Lula". ${ }^{73}$ Segundo o arcebis-

${ }^{69}$ Gaspari, Elio. O debate do aborto, Miriam Cordeiro 2.0. O Globo, 10 out. 2010, O País, p. 11.

${ }^{70}$ Dilma muda estratégia e parte para o ataque direto a Serra. No primeiro debate do segundo turno, um duelo sobre aborto e privatização. O Globo, 11 out. 2010, p.1.

${ }^{71}$ Dilma e Serra trocam acusações sobre aborto em debate na TV. 10/10/2010 - 22h42min. Disponível em: <http: /www1.folha.uol.com.br/poder/812820-dilma-e-serratrocam-acusacoes-sobre-aborto-em-debate-natv.shtml> Acesso em: 16 nov. 2013.

${ }^{72}$ Opinião: planejamento familiar é mais relevante. O Globo, 12 out. 2010 , O país, p. 6 .

${ }^{73}$ Vasconcelos, Adriana. Arcebispo ataca Dilma e PT na internet: Dom Aldo Pagotto diz que petista e partido se comprometeram com a 'cultura da morte'; religioso faz críticas a Lula. O Globo, 12 out. 2010, O país, p.13. 
po, o PT teria assumido como projeto de governo a completa legalização do aborto, apesar de negar isso nas últimas semanas. Merval Pereira comenta pesquisa do Datafolha, mostrando que o aborto teve menos peso na mudança de votos do que as denúncias de corrupção no Gabinete Civil. ${ }^{74} \mathrm{~A}$ posição de autoridades da hierarquia da Igreja Católica denunciando o PT como contrário ao aborto continua no foco da cobertura.

\section{As revistas enfocam aborto e religião nas eleições}

No fim de semana prolongado do feriado de 12 de outubro, o tema aborto foi matéria de capa de três revistas de circulação nacional: Veja, Época e Carta Capital. A matéria de Veja aborda as mudanças de posição da candidata do PT, em particular quanto ao aborto, citando, na capa, a posição da entrevista de 2007, favorável à descriminalização do aborto e de 2010, às vésperas do primeiro turno, dizendo-se pessoalmente contrária. A reportagem também acusa o partido de esconder sua bandeira favorável à descriminalização e mostra (com foto) três lideranças religiosas condenando o aborto: Wilton Acosta (presidente do Fórum Evangélico Nacional de Ação Social e Política), o bispo de Guarulhos Dom Luiz Gonzaga Bergonzini e Geraldo Campetti (diretor executivo da Federação Espírita Brasileira), além de duas outras alertando contra o voto em Dilma: o pastor Silas Malafaia em carta aberta citada acima e o padre José Augusto em missa transmitida pela TV Canção Nova. A matéria seguinte enfoca o aborto com respeito à falta de consenso sobre início da vida, o mapa do aborto com a legislação em vários países, a legislação brasileira e os resultados do aborto clandestino no Brasil. Após apresentar os dados dos custos das internações decorrentes do aborto inseguro aqui, a reportagem muda de direção e conclui que seria mais caro realizar as curetagens no serviço público e "mais barato fazer campanhas

\footnotetext{
${ }^{74}$ Pereira, Merval. Tática arriscada. O Globo, 12 out. 2010, O país, p.4.
}

educativas em favor da anticoncepção". ${ }^{75}$

A matéria de capa de Época enfoca a influência do debate sobre aborto e religião no segundo turno. A matéria retoma declarações de Dilma Rousseff favoráveis à descriminalização do aborto, anteriores à sua candidatura, que teriam sido "munição" (sic) para uma campanha contrária a ela e que teriam desviado votos para Marina Silva. Outro ponto de destaque é a mudança na campanha eleitoral, com o ataque do PSDB ao ponto vulnerável do adversário, e reforço de seu contato com líderes religiosos, por um lado, e o programa do PT usando os depoimentos de líderes católicos e evangélicos como Manoel Ferreira da Assembleia de Deus e do deputado Gabriel Chalita ligado à Renovação Carismática Católica para desmentir que a candidata seria favorável ao aborto. Além da posição liberal do PT com respeito à homossexualidade, a matéria destaca manifestações e documentos no meio católico e evangélico que orientavam a não votar em Dilma Rousseff ou em candidatos do PT, por conta da posição "pró-aborto" do partido. ${ }^{76}$ Quatro pesquisadores da religião são citados entre as fontes: o antropólogo Ari Oro e os sociólogos Ricardo Mariano, Edin Abumanssur e Antônio Flávio Pierucci.

Com orientação política assumidamente de esquerda, a revista Carta Capital denuncia como oportunismo eleitoral a emergência do tema aborto na campanha. O "clima inquisitorial" (sic) teria sido patrocinado por evangélicos e por alas conservadoras da Igreja Católica. Em um dos parágrafos iniciais, o artigo cita as estatísticas do SUS sobre aborto clandestino, responsável por 15\% da mortalidade materna no país, a realização de curetagens pelo SUS, e cita a pesquisa feita pela UnB segundo a qual uma em cada cinco brasileiras com menos de 40 anos já abortou "por vontade própria". O restante da matéria aborda o de${ }^{75}$ Coutinho, Leonardo; Cabral, Otávio; Segalla, Vinícius.
Antes; depois. Veja, ano 43, n. 41, 13 out. 2010, p. 6267. Lopes, Adriana Dias; Ming, Laura. Voltamos à pergunta: quando começa a vida. Veja, ano 43, n. 41, 13 out. 2010, p. 68-70.

${ }^{76}$ Martins, Ivan; Rocha, Leonel. A fé entrou na campanha. Como o debate sobre Deus e o aborto interfere no segundo turno das eleições - e pode inaugurar uma nova fase na política brasileira. Época, n. 647, 11 out. 2010, p. 40-45. 
senrolar da polêmica. É citada a atuação de bispos católicos com apelo para não votar em candidatos do PT. A proposta de "recomendar ao Legislativo a adequação do Código Penal para a descriminalização do aborto", presente no Programa Nacional de Direitos Humanos, teria virado "legalização do aborto até nove meses de gestação”. A revista também descreve a articulação da campanha do PT com parlamentares evangélicos e católicos para fazer a reação, com a distribuição da carta "Ao povo de Deus", em que a candidata afirma a "prerrogativa do Parlamento decidir sobre temas como aborto e uniões estáveis", bem como o caráter laico do Estado garantido pela Constituição. O artigo mostra divisões internas da Igreja Católica, inclusive a nota oficial da CNBB sobre as eleições, que não cita partidos ou candidatos. A matéria comenta informações da Pesquisa Nacional de Aborto feita pela UnB na conclusão do texto, a partir de uma de suas autoras, a antropóloga Debora Diniz. Os resultados mostram que a maioria dos abortos foi realizada por católicas e, em seguida, por protestantes e evangélicas, além de revelar as condições inseguras da prática, fato relacionado à ilegalidade. A conclusão do artigo relembra que José Serra, quando Ministro da Saúde, normatizou o aborto legal em 1998 e, embora tenha sido alvo de condenação pela CNBB na época, usa agora o tema como arma eleitoral. Associada à matéria está uma entrevista com a coordenadora da ONG Católica pelo Direito de Decidir, para quem o aborto deve ser tratado como tema de saúde pública, e o Estado não deve se submeter às religióes, pois isso violaria a separação entre Estado e Igreja. ${ }^{77}$

\section{Aborto: pressão dos religiosos resulta na "Car- ta de Dilma"}

No dia 13 de outubro, Zuenir Ventura analisa o uso do tópico aborto como arma de campanha: "troca de acusações pautada pela hipocrisia".

${ }^{77}$ Menezes, Cynara. Na Idade Média. Sem qualquer relação com o problema que leva milhares de mulheres à morte todos os anos, o debate sobre o aborto virou uma arma dos conservadores. Carta Capital, ano XVI, N. 617, 13 out. 2010, p. 20-25. É abominável. Nunes, Maria José Rosado; Lírio, Sergio. Carta Capital, ano XVI, N. 617, 13 out. 2010, p. 25.
Lembra ser o aborto a causa de morte de uma brasileira a cada dois dias, e lamenta que esse problema social grave não incentive o debate, mas seja "usado como máquina de guerra eleitoral", citando o jornal francês Le Monde..$^{78}$ No dia seguinte, o assunto volta à primeira página, com a manchete "Dilma lançará 'carta' contra o aborto e o casamento gay: 'Não mandarei ao Congresso nenhuma legislação que impacte na religião"'. A matéria prossegue na página interna com o título "A carta de Dilma: pressionada por evangélicos, petista aceita assinar texto contra aborto e casamento gay". ${ }^{79}$ Dilma defende sua posição dizendo que o Estado laico não irá interferir em questões religiosas e, por isso, não enviará projeto ao Congresso Nacional. Estiveram presentes à reunião 51 pastores, bispos e parlamentares ligados a igrejas evangélicas. São citados o senador Marcelo Crivella, o deputado Eduardo Cunha (PMDB-RJ) da Igreja Sara Nossa Terra, deputados petistas evangélicos Walter Pinheiro (PT-BA) e Gilmar Machado (PT-MG), além do pastor Everaldo Pereira (vice-presidente do PSC).

As críticas ao Programa Nacional de Direitos Humanos (PNDH 3) são retomadas em 15 de outubro: "Em meio à polêmica, ministro defende PNDH: em nota, Vanucchi diz que Programa de Direitos Humanos, que mudou, não prevê legalização do aborto. ${ }^{80}$ Outra notícia, na mesma data, mostra o esforço do PT para redirecionar a campanha: "Campanha petista busca agenda positiva: ideia é evitar polêmicas como aborto e outras questões religiosas". ${ }^{81}$ Ainda nessa data, é publicado o artigo de opinião "Religião e eleições" de Maria das Dores C. Machado, ${ }^{82}$ socióloga da religião. A

${ }^{78}$ Ventura, Zuenir. Pacto sobre o aborto. O Globo, 13 out. 2010, Opinião, p. 7.

${ }^{79}$ Dilma lançará ‘Carta' contra o aborto e o casamento gay: 'Não mandarei ao Congresso nenhuma legislação que impacte na religião'. O Globo, 14 out. 2010, p. 1. Menezes, Maia. A carta de Dilma: Pressionada por evangélicos, petista aceita assinar texto contra aborto e casamento gay. O Globo, 14 out. 2010 , p. 14.

${ }^{80}$ Em meio à polêmica, ministro defende PNDH: em nota, Vanucchi diz que Programa de Direitos Humanos, que mudou, não prevê legalização do aborto. O Globo, 15 out. 2010, O País, p. 15.

${ }^{81}$ Lima, Maria. Campanha petista busca agenda positiva: ideia é evitar polêmicas como aborto e outras questões religiosas. O Globo, 15 out. 2010, O País, p. 17.

${ }^{82}$ Macgado, Maria das Dores C. Religião e eleições. O Globo, 15 out. 2010 , Opinião, p.7. 
socióloga analisa a divisão de apoios políticos na campanha eleitoral tanto por parte da Igreja Católica como no campo evangélico, "caracterizado por sua heterogeneidade e por intensa competição entre grupos confessionais", e conclui que o voto dos grupos mais inflexíveis contra o aborto (católicos, evangélicos e espíritas) se distribuiu entre Marina Silva, José Serra e Dilma Rousseff. Ela lança sua intervenção política no debate: em vista dessa divisão, não faria sentido “[...] pautar o debate pelos temas morais que só interessam aos tradicionalistas e fortalecem os atores religiosos que procuram fazer de uma questão que atinge milhares de mulheres brasileiras uma moeda de troca no jogo eleitoral". A autora alerta ainda que as mais pobres são as mais prejudicadas pela criminalização.

A estratégia eleitoral da candidata do PT continua sob foco, em matéria do dia 16 de outubro: "Dilma e a 'premissa do Evangelho': petista cede à pressão de grupos religiosos e assina carta, que será distribuída nas igrejas, dizendo-se contra aborto". Esse folheto "Mensagem de Dilma” teria o objetivo de fazer cessar "a campanha de calúnias e boatos" espalhados por "adversários eleitorais", e foi publicado na íntegra por O Globo. São citados o pastor Manoel Ferreira e o Senador Marcelo Crivella. ${ }^{83}$ No mesmo dia, é publicada uma crônica carregada de ironia, em que João Ximenes Braga afirma ser a defesa da legalização do aborto e do casamento gay a melhor estratégia para a vitória, não importando a convicção. Citando estatísticas, Braga alega que o número de votos obtidos com mulheres que praticaram o aborto e pessoas que têm parceiro do mesmo sexo superaria o dos votos religiosos. ${ }^{84}$ No domingo 17 de outubro, é entrevistada Regina Novaes, antropóloga pesquisadora da área de religião, política e juventude. Ela comenta sobre as alianças inesperadas no Congresso Nacional contra a descriminalização do aborto e salienta a novidade na campanha presidencial quando o "suposto conservadorismo evangélico é valo-

${ }^{83}$ Farah, Tatiana; Suwwan, Leila. Dilma e a 'premissa do Evangelho’: petista cede à pressão de grupos religiosos e assina carta, que será distribuída nas igrejas, dizendo-se contra aborto. O Globo, 16 out. 2010, O País, p. 11. A íntegra da carta. O Globo, 16 out. 2010, O País, p. 11. rizado (e ecumenicamente se soma a setores da Igreja Católica)." Além da "linguagem pseudorreligiosa" usada por candidatos "em competição para provar quem tem mais fé", ela critica como a "pior mistura" de religião e política ver "uma elite política e católica do Sudeste que busca os setores evangélicos mais conservadores para colocar em questão a fé pessoal na disputa eleitoral" ${ }^{85}$ Após a assinatura da carta, os evangélicos praticamente desaparecem da cobertura das eleições, faltando ainda 11 dias para o segundo turno. É possível interpretar que, tendo conseguido o compromisso, eles recuam da frente da cena. Esse protagonismo com pressão sobre o candidato pode representar certo estilo de fazer política, característico da Igreja Universal do Reino de Deus, que será analisado adiante (Oro, 2003). A cobertura da imprensa também parece se esquecer dos evangélicos.

\section{Telhado de vidro: a acusação de aborto con- tra Mônica Serra}

A denúncia de um fato na vida pessoal do candidato Serra é uma exceção no foco contínuo sobre sua adversária. Em 17 de outubro, O Dia traz, na primeira página, a manchete "Ex-aluna diz que mulher de Serra fez um aborto. Para tucanos, é 'jogo sujo". Conforme a matéria, Monica Serra, que acusou Dilma Rousseff de ser a favor de "matar criancinhas" por sua posição favorável ao aborto, teria confidenciado a alunas ter feito um aborto quando o marido estava exilado no Chile. Sheila Ribeiro, a ex-aluna, divulgou o relato no site de relacionamentos Facebook. O jornal também publica nota da assessoria de imprensa da campanha de José Serra que desmente a acusação e remete a acusação semelhante feita a Lula na eleição de 1989. ${ }^{86}$ Segundo Ramos (2012), a acusação de ${ }^{84}$ Braga, João Ximenes. Jogo de tabuleiro. O Globo, 16 out. 2010, Ela, p. 2.

${ }^{85}$ Novaes, Regina (entrevista). 'Há competição para provar quem tem mais fé’: pesquisadora da área de religião e política aponta retrocessos no discurso que tomou conta da campanha eleitoral. O Globo, 17 out. 2010, O País, p. 17.

${ }^{86}$ Ex-aluna diz que mulher de Serra fez um aborto. Para tucanos, é 'jogo sujo'. O Dia, 17 out. 2010, p.1. Nascimento, Cristina; Noé, João. Ex-aluna afirma que Monica 
Mônica Serra contra Dilma teria acontecido durante campanha eleitoral na Baixada Fluminense em setembro de 2010, ainda no primeiro turno. No primeiro debate do segundo turno, em 10 de outubro, Dilma Rousseff acusou José Serra de campanha de difamação e citou a acusação feita por sua esposa. A ex-aluna, motivada pelo debate, teria divulgado a confidência. Ainda segundo Ramos (2012), José Serra teria sido vítima do "efeito fariseu" (Pierucci, 2011): ao construir uma imagem de correção moral e adesão a valores religiosos, questionando-os em sua adversária, abriu espaço para o exame de sua própria vida pessoal.

\section{A última ofensiva dos religiosos antiaborto: 0 protagonismo católico}

Na edição dominical de $O$ Globo de 17 de outubro, a coluna de Caetano Veloso, de título "Aborto e casamento gay", compara a atitude honesta e franca de Marina Silva, notoriamente religiosa, e critica José Serra e Dilma Rousseff por se agarrarem "nos aspectos mais primários da marola religiosa". Lamenta ver a candidata do PT ao lado de crentes que querem lhe arrancar o compromisso de não fazer casamento gay e legalização do aborto. ${ }^{87}$

Na mesma data, o Dia publica uma entrevista com Dom Fillipo Santoro, bispo de Petrópolis. Indagado sobre a posição contrária de vários setores da Igreja à candidatura de Dilma Rousseff, o bispo alega, primeiramente, a participação da Igreja Católica no processo que levou à aprovação da Lei da Ficha Limpa, não havendo o povo ficado indiferente aos "escândalos" (sic) na vida política do país, e como segundo motivo a defesa da vida desde a concepção. O bispo critica também o Programa Nacional de Direitos Humanos (PNDH 3), considerando um "remendo" (sic) insuficiente a retirada da questão do aborto do PNDH 3, "falaciosamente con-

Serra contou que fez um aborto. "Coreógrafa publicou na Internet que mulher de candidato falava da experiência traumática na sala de aula”. O Dia, 17 out. 2010, Especial, p. 8. Para PSDB: ‘jogo sujo'. O Dia, 17 out. 2010, Especial, p. 8.

${ }^{87}$ Veloso, Caetano. Aborto e casamento gay. O Globo, 17 out. 2010, Segundo Caderno, p. 2. siderada “questão de saúde pública”'. Ressalta que o Estado é "leigo, mas não ateu”, e "deve respeitar a religiosidade das pessoas e das agregações sociais" ${ }^{88} \mathrm{O}$ jornal também publica uma matéria com Dom Orani Tempesta, arcebispo do Rio de Janeiro, revelando sua intenção de proibir a distribuição de panfletos políticos em igrejas e sua crítica à propaganda nas missas. ${ }^{89}$

Notícia em 19 de outubro comenta nota da Regional Leste 1 da CNBB: "Bispos recomendam voto em quem defenda a vida. Em nota, religiosos fluminenses repudiam união gay e aborto; arquidiocese do Rio ratifica". ${ }^{90}$ Apenas em 21 de outubro é vista uma reação à matéria de ODia, que acusa a esposa de José Serra de ter feito um aborto. Analisando a agressividade que tomou conta da campanha eleitoral, Merval Pereira, em sua coluna, comenta que ativistas da campanha petista estariam espalhando pela Internet "calúnias contra a mulher do candidato José Serra a respeito de aborto". Segundo o colunista, a questão do aborto teria entrado no debate político por conta do PNDH 3 , o que gerou reação de setores religiosos. Comenta o documento da CNBB com a lista das medidas e compromissos assumidos pelo governo Lula de legalizar o aborto com a recomendação de escolher candidatos "a favor da vida". ${ }^{11}$ É importante observar que o PNDH 3 foi alterado em maio de 2010, quatro meses antes da cobertura da campanha eleitoral aqui analisada, tendo sido retirado o item referente ao aborto, que propunha: "Apoiar a aprovação do projeto de lei que descriminaliza o aborto, considerando a autonomia das mulheres para decidir sobre seus corpos". Foi mantido o item que previa monitoramento dos serviços e acesso ao aborto "legalmente autorizado". A decisão foi

${ }^{88}$ Molica, Fernando. Entrevista Dom Fillipo, Bispo de Petrópolis: 'Tirar aborto do plano é remendo'. O Dia, 17 out. 2010, Especial, p. 7.

${ }^{39}$ Alves, Francisco Edson. Arcebispo do Rio quer fim da guerra religiosa. Dom Orani Tempesta proíbe distribuição de panfletos políticos em igrejas católicas e critica propaganda nas missas. O Dia, 17 out. 2010, Especial, p. 6.

${ }^{90}$ Galdo, Rafael. Bispos recomendam voto em quem defenda a vida; em nota, religiosos fluminenses repudiam união gay e aborto; arquidiocese do Rio ratifica. O Globo, 19 out. 2010, O País, p. 17.

${ }^{91}$ Pereira, Merval. Baixos instintos. O Globo, 21 de outubro de 2010, O País, p. 4. 
uma vitória dos grupos antiaborto (Luna, 2014). A despeito disso, o programa continua sendo citado como argumento por algumas lideranças religiosas que constam na cobertura jornalística.

No domingo, 24 de outubro, O Estado de $S$. Paulo traz na primeira página: "PT é partido da morte' acusa bispo de Guarulhos". Segundo D. Luiz Gonzaga Bergonzini, que mandou fazer dois milhões de cópias do folheto "Apelos a todos os brasileiros e brasileiras", o PT “[...] aceita o aborto até o nono mês de gravidez. Isso é assassinato de ser humano que não tem nem o direito de se defender". Segundo a reportagem, ele seria a voz dentro da Igreja Católica que coloca Dilma Rousseff no centro da polêmica sobre o aborto. ${ }^{92}$

Em 25 de outubro, dois artigos da página de Opinião de $O$ Globo tematizam o aborto. O artigo de Denis Lerrer Ronsenfield, filósofo e professor da UFRGS, comenta a irrupção "dogmática" (sic) da questão do aborto na eleição presidencial e, por isso, pretende colocar seu significado em termos racionais. O argumento favorável ao aborto estaria baseado no princípio da liberdade de escolha da mulher, mas uma escolha que opera "sobre um 'ser', que em um sentido é ela e em outro não o é". O problema consistiria em "determinar onde começa o "humano". A liberdade de escolha da mulher encontraria um limite na liberdade "de um ser humano no processo de vir a ser". Rosenfield aplica esse princípio aos dois casos de aborto permitidos pela legislação brasileira e, em seguida, questiona como deveriam ser tratados os casos concretos de mulheres que recorreram ao aborto em contradição com a lei. Seguindo a lei, elas "deveriam ser criminosas, julgadas e presas". O autor considera a situação de mulheres que chegam a um hospital público com complicações decorrentes de um aborto clandestino, ou que morrem sem buscar atendimento por medo de serem consideradas infratoras, que são mais frequentemente pessoas de baixa renda. Por envolver conflito de prin-

${ }^{92}$ Macedo, Fausto. Bispo diz que 'PT é o partido da morte': para D. Bergonzini, que mandou fazer 2 milhões de cópias do folheto 'apelos a todos brasileiros e brasileiras', PT aceita aborto até $9^{\circ}$ mês de gravidez. O Estado de S. Paulo, 24 out. 2010, Nacional, p. A12. cípios, implicando consequências para as mulheres, o aborto não deveria ser decidido no calor de um embate eleitoral..$^{93} \mathrm{O}$ artigo da psicanalista Glaucia Dunley considera que a prática do aborto envolve "o direito à vida e o direito à liberdade". Segundo Dunley, o debate trazido pela mídia em torno dos candidatos estaria "[...] tentando acorrentá-los com os grilhões maniqueístas e excludentes da apropriação moral, religiosa ou tecnocrata em termos de saúde”. Em sua chave psicanalítica, a autora considera uma decisão trágica que cada mulher é obrigada a tomar sozinha. A “[...] questão política levantada pela possibilidade de uma prática descriminalizada do aborto solicita a elaboração de leis que tenham como ideal 'um direito justo", o qual seria capaz de considerar a convivência problemática entre seres humanos. ${ }^{94}$ Um último artigo de opinião, no dia 28 de outubro, reta final da campanha, do administrador de empresas João Luiz Mauad também comenta o lugar de destaque que o aborto ocupou no segundo turno das eleições. Ele qualifica de utilitarista o argumento apresentado pela então ministra Dilma Rousseff, segundo a qual o aborto seria uma questão de saúde pública, porque uma quantidade enorme de mulheres brasileiras morre ao realizar um aborto em condições precárias, comparando-o a legalizar práticas de risco como o roubo ou o homicídio. Coloca o debate "sério, laico e racional" em termos da soberania da mulher sobre o próprio corpo e de estabelecer o momento de início da vida humana. Recomenda que, na dúvida, se “... poupe a vida, afinal existe a possibilidade real de que o aborto provocado seja equivalente a um homicídio". ${ }^{55}$ Os três últimos artigos de opinião encontrados no levantamento abordam o aborto em termos morais como uma questão de liberdade de escolha, contrastada ao direito à vida, sendo que o de Mauad e o de Rosenfeld claramente tomam partido do direito do feto. Nesse sentido,

${ }^{93}$ Ronsenfield, Denis Lerrer. Aborto. O Globo, 25 out. 2010, Opinião, p. 6.

${ }^{94}$ Dunley, Glaucia. Em busca de um direito justo. O Globo, 25 out. 2010 , Opinião, p. 7.

${ }^{95}$ Mauad, João Luiz. Um assunto muito sério. O Globo, 28 out. 2010 , Opinião p.7. 
eles continuam a tendência manifesta ao longo da controvérsia de não considerar a situação do aborto no Brasil a partir da análise dos dados sobre as consequências do aborto clandestino. As feministas estiveram praticamente ausentes dessa discussão, e os especialistas em religião comentaram a apropriação de conservadores e de religiosos do aborto para suas estratégias eleitorais, mas não discutiram a situação do aborto em si.

$O$ fato de maior impacto, nas vésperas do segundo turno, foi um discurso do Papa Bento XVI, manchete de primeira página de $O$ Globo, em 29 de outubro: "Pressão de bispos dá certo e Papa interfere na eleição; Dilma diz que não será prejudicada; para Serra, orientação é legítima”. O Papa declarou, para bispos da Regional Nordeste 5, que o episcopado tem o dever de emitir juízo moral mesmo em matérias políticas e criticou propostas de descriminalização do aborto e da eutanásia. A posição do Papa seria resultado da mobilização de bispos conservadores. ${ }^{96}$ Respondendo à demanda dos segmentos mais conservadores do episcopado católico, o Papa se manifesta contra o aborto e pela responsabilidade da Igreja de intervir no processo político. Sua argumentação contraria o pressuposto moderno que separar Igreja e Estado supõe o não envolvimento da religião na política (Giumbelli, 2002a). Esse envolvimento foi registrado pela grande imprensa ao longo da campanha apenas com respeito à posição do lado conservador da Igreja, de modo que as manifestações dos progressistas a favor da candidatura do PT foram divulgadas em outros espaços midiáticos, conforme identificado por Machado (2012).

\section{O segundo turno: a posição dos analistas so- bre aborto e religião}

No dia do segundo turno, tanto $O$ Globo como O Estado de S. Paulo incluíram o aborto en-

${ }^{96}$ Pressão de bispos dá certo e Papa interfere na eleição; Dilma diz que não será prejudicada; para Serra, orientação é legítima. O Globo, 29 out. 2010, p. 1. Camarotti, Gerson. Interferência papal: mobilização de bispos faz Bento XVI defender participação do episcopado em questões políticas. O Globo, 29 out. 2010, p. 3. tre os tópicos marcantes da eleição, associado à pressão de grupos católicos e evangélicos. ${ }^{97} \mathrm{~A}$ primeira página de $O$ Estado de $S$. Paulo trazia a manchete "Religião e moral dominam campanha de modo inédito". A reportagem continua com o título "A mais religiosa de todas as campanhas: por pressão principalmente das igrejas, questões como aborto e a união estável homossexual ganharam este ano relevância nunca vista em eleições anteriores". ${ }^{98}$ O texto, de caráter analítico, apresenta a posição de diversos especialistas. O sociólogo Reginaldo Prandi conclui que o debate em torno dos temas religiosos foi um elemento desestabilizador para Dilma Rousseff não ter vencido no primeiro turno. A socióloga da religião Maria das Dores Campos Machado destaca o surgimento do ativismo religioso de grupos em defesa da vida, condenando o aborto, que vetaram candidatos e partidos, com ênfase no tema moral, o que levou a disputas entre bispos da Igreja Católica, e entre líderes evangélicos, disputas marcadas pela troca de favores por apoio eleitoral. O sociólogo Luiz Alberto Gomez de Souza considera que houve instrumentalização da questão religiosa sem precedentes, em especial ao se cobrar dos candidatos uma definição pessoal sobre o aborto. Para o padre, teólogo e historiador José Oscar Beozzo, a novidade da campanha foi a entrada de um lobby contra o aborto "fazendo dele a questão única”. Beozzo recorda a posição do presidente da CNBB, D. Geraldo Lyrio, para quem o aborto não poderia ter ficado fora do debate eleitoral, aconselhando os católicos a escolherem pessoas comprometidas com valores éticos e a defesa da vida, sem citar nomes de candidatos.

O sentido dessa presença dos cientistas sociais na polêmica, com maior representatividade dos estudiosos de religião, é um elemento a se considerar na cobertura. Um exemplo do engajamento desses pesquisadores no debate é o artigo do sociólogo Antônio Flávio Pierucci publicado na seção

\footnotetext{
${ }^{97}$ Da campanha para a História. O Globo, 31 out. 2010, O País, p.45. Manzano, Gabriel. Memórias de campanha. O Estado de S. Paulo, 31 out. 2010, Especial, p. H20.

${ }^{98}$ Religião e moral dominam campanha de modo inédito. O Estado de S. Paulo. 31 out. 2010, p. 1. Mayrink, José Maria. A mais religiosa de todas as campanhas. O Estado de S. Paulo. 31 out. 2010, Especial, p. H15.
} 
opinião de um periódico científico (2011), comentando o resultado do segundo turno logo após o fim das eleições. O autor denuncia a quebra da expectativa de a eleição ser decidida por uma onda de votos religiosos no segundo turno:

Contrariando as expectativas de quem apostara nessa tática divinamente apoiada e frustrando as expectativas dos que haviam botado a boca no trombone da internet contra um futuro iminente de aborto permitido, homofobia rechaçada e PNDH 3 aprovado e sancionado, o tratamento eleitoreiro de questões de teor moralista com fundamento religioso não conseguiu se segurar como um eixo em torno do qual se decidisse um número importante de votos. Sua relativa capacidade de persuadir durou pouco, mesmo para um jogo político de curtíssima duração (Pierucci, 2011, p. 14).

É importante a ressalva que, embora não tenha decidido o segundo turno das eleições, essa curta duração foi a oportunidade de mobilização de grupos religiosos antiaborto para se afirmarem na cena pública, a ponto de arrancar um compromisso da candidata do PT de que o Poder Executivo não enviaria ao Congresso Nacional projeto legislativo sobre a matéria. Tal acordo é relevante, pois contrasta com o governo Lula, que constituiu uma comissão tripartite de revisão da legislação punitiva sobre o aborto (Gomes; Menezes, 2008). Vários outros especialistas foram chamados pela imprensa para elucidar o dito fenômeno do "voto religioso" e passaram a integrar o debate público que analisaram. Giumbelli (2002a, p. 426) afirma que os cientistas sociais são chamados a "fixar o religioso". Retomando a definição de Giumbelli (2002b, p. 97), “[...] a controvérsia é uma espécie de drama social, que revela mas também reconfigura definições de realidade, explicitando o conflito que existe em torno dessas definições". Na cobertura da campanha eleitoral, a ênfase na mobilização dos agentes religiosos e em seus padrões de votação sugere que a posição dos religiosos é a dimensão problemática e que o aborto, aparentemente o cerne da controvérsia, era só um sinal diacrítico acerca da moral dos candidatos, posto que o debate sobre a situação do aborto no Brasil, em si, praticamente esteve ausente tanto da cobertura jornalística como dos artigos de opinião. Essa conclusão foi alcançada também por Fontes (2012, p. 1811-1812), que identificou "[...] um silêncio praticamente absoluto em relação aos aspectos da saúde da mulher, da criminalização e das consequências sanitárias e legais a serem enfrentadas por políticas públicas". A despeito do aumento exponencial das menções ao aborto nas matérias da grande imprensa, principalmente no mês de outubro, tendência registrada desde o final de setembro, o conjunto da cobertura revela não uma controvérsia centrada nos discursos sobre o aborto, objetivo primeiro do presente artigo, mas um retrato do conservadorismo moral espelhado na dinâmica de acusações presentes na campanha eleitoral. Os protagonistas seriam os religiosos conservadores, tema de muitos artigos de opinião e da análise de especialistas. Não são representados como integrantes dessa controvérsia atores engajados no debate sobre aborto: as feministas e os profissionais da área de saúde que investigam o tema e suas implicações, pois sua aparição foi bastante escassa na cobertura da grande imprensa. A ênfase é, antes, na participação de lideranças religiosas e de políticos de sustentação da base de Dilma, praticamente todas constituídas de evangélicos, tecendo alianças e arrancando um compromisso, e, na oposição, quase sempre personagens da hierarquia católica que consideravam o aborto personificado na candidatura à presidência pelo PT. No segundo turno, representam-se Dilma Rousseff e José Serra buscando o apoio desses religiosos e ostentando sinais de fé, ponto de dar margem ao "efeito fariseu": "[...] quando a ventilação eleitoral de temas, critérios e apelos religiosos obtém do eleitor conservador resposta contrária à esperada" (Pierucci, 2011, p. 9), com o reconhecimento do uso eleitoral da religião.

\section{CONSIDERAÇÕES FINAIS}

O tema do aborto não é muito frequente na cobertura da mídia no Brasil, considerando os jornais de circulação nacional. No período da campanha presidencial, em particular nas vésperas do 
primeiro turno e no segundo turno, o número de menções à palavra cresceu em proporção elevadíssima: quase metade das citações do ano de 2010 ocorreu no mês de outubro. O pico da frequência das matérias com referência a aborto, quase diária, está nas duas primeiras semanas de outubro, o que coincide com a véspera do primeiro turno, e os dez primeiros dias do segundo turno. Depois, a frequência de notícias cai. Por outro lado, nas entrevistas de candidatos ao Legislativo e ao Executivo, foi constante a pergunta sobre a posição quanto ao aborto, mesmo antes de a polêmica se armar nas vésperas do segundo turno, o que leva a indagar qual o interesse jornalístico na posição pessoal de candidatos. No tocante aos atores citados nas matérias ou suas fontes, constatouse presença reduzida de especialistas, em sua maioria pesquisadores de religião, com poucas referências a outros que investigam o aborto. A menção a lideranças feministas foi mínima. Verificou-se número muito pequeno de matérias de exame da situação do aborto no Brasil, em geral repetindo os resultados da pesquisa de aborto no Brasil procedente da UnB e a pesquisa sobre aborto como problema de saúde pública promovida pelo Ministério da Saúde. Quanto aos artigos de opinião, raros foram os de autores com pesquisa sobre aborto ou na área de religião, embora os especialistas sobre religião tenham sido citados como fontes em vários artigos, em contraste com os pesquisadores sobre aborto. A maior parte das matérias descreveu o jogo político com ênfase especial nos atores religiosos.

A cobertura destacou a participação da Igreja Católica, quase sempre na figura de seus representantes mais conservadores, voltados para a defesa da vida e publicamente contrários à eleição da candidata do PT. A novidade foi o amplo enfoque nos evangélicos durante o período imediatamente anterior e posterior ao primeiro turno, no exemplo de políticos com cargos parlamentares e das lideranças de diversas igrejas nessa porção fragmentada do campo religioso. Com respeito aos candidatos à presidência, a cobertura mostra os evangélicos divididos desde o primeiro turno no apoio a Marina Silva, José Serra ou Dilma Rousseff. No segundo turno, a articulação política da campanha do PT para arrebanhar apoio dos religiosos e superar o tema do aborto como acusação foi descrita pela imprensa como chantagem por parte dos evangélicos, que buscavam o compromisso de campanha de não alterar a legislação sobre o aborto. Das lideranças religiosas da parte católica, quase todos os citados são bispos contrários a Dilma Rousseff, com destaque para D. Luiz Gonzaga Bergonzini, de Guarulhos. Entre os evangélicos, a cobertura frisa o oposto: quase todos os mencionados estão na campanha do PT e poucos contrários aparecem. As lideranças evangélicas citadas são praticamente as mesmas: na oposição a Dilma Rousseff, o pastor Silas Malafaia. Mas os apoiadores aparecem mais vezes sendo os mais citados: Manoel Ferreira (presidente da Convenção das Assembléias de Deus do Ministério Madureira), identificado como coordenador da campanha entre os evangélicos, senador Marcelo Crivella, deputado Robson Rodovalho, bispo da Igreja Sara Nossa Terra, deputado Eduardo Cunha. O bispo Edir Macedo é citado apenas no primeiro turno. O destaque dado às lideranças e a políticos evangélicos na campanha contrasta com a preferência do eleitorado evangélico, que foi o segmento religioso em que a candidata do PT obteve desempenho mais fraco: pesquisa do IBOPE no dia do segundo turno, considerando voto e afiliação religiosa, "[...] revelou que Dilma venceu por larga margem entre os eleitores católicos (58\%), mas praticamente empatou com o seu adversário entre os evangélicos (52 a $48 \%$ dos votos)" (Machado, 2012, p. 40).

Considerando o conjunto das matérias, pouco se expôs sobre a situação do aborto no Brasil, embora os autores dos artigos de opinião, os especialistas, os religiosos e os políticos consultados tivessem opinião a respeito. O tema do aborto, retratado na cobertura da imprensa em termos nitidamente estigmatizantes, foi associado, em proporção bem maior, à candidata do PT. As referências à normatização do aborto legal no SUS feita por José Serra, quando Ministro da Saúde, ou mesmo as acusações referentes à sua vida privada foram pouco apresentadas, em contraste com a retomada de 
entrevistas da então ministra Dilma Rousseff, ou da presença do tema legalização do aborto no programa do PT, suas convenções partidárias ou no PNDH-3, pontos sistematicamente repetidos em várias matérias. As críticas à exposição pública de atividades religiosas com propósitos eleitoreiros foram dirigidas a ambos os candidatos. Entre os artigos de opinião, esteve mais presente a crítica à exploração política do tema aborto do que uma análise da situação do aborto no Brasil. Nesses textos, foi mais frequente a reflexão abstrata em termos filosóficos, ou quanto aos valores que opõem o direito à liberdade e o direito à vida, do que um panorama da situação concreta.

Concordando com Machado (2012), verificou-se que os grandes veículos de comunicação nacional exploraram mais os ataques dos segmentos religiosos conservadores ao PT e a sua candidata do que as posições favoráveis dos progressistas. $\mathrm{O}$ levantamento do material de imprensa permitiu tais constatações. É necessário, agora, um esforço analítico na direção de uma abordagem que interprete esses resultados, em particular a ênfase da cobertura na dimensão religiosa e em seus atores. ${ }^{99}$

Duas dimensões podem ser consideradas: uma delas é a atuação política de lideranças das igrejas e parlamentares religiosos nesse debate. Outra diz respeito às crenças e valores religiosos e laicos que cercam o tópico aborto. Enfoco, primeiramente, a dimensão institucional e seus atores. Em artigo sobre a inserção da Igreja Universal do Reino de Deus na política nacional e seus efeitos no campo religioso e político, Oro (2003) comenta sobre o efeito mimético produzido pela IURD sobre outras igrejas evangélicas quanto à imitação de seu modo de fazer política. Isso pôde ser observado nas vésperas do primeiro turno, com o apoio público e a denúncia por políticos e lideranças religiosas de uma campanha de boatos contra Dilma Rousseff. Esse modo de fazer política foi constatado também no momento posterior ao segundo tur-

${ }^{99}$ Embora não tenha sido o objetivo inicial deste artigo, ao fazer o levantamento na imprensa, a pesquisa coincide com a proposta de Giumbelli sobre um estudo da religião que não toma grupos religiosos concretos como objeto (2002a, p. 18). no, com a assinatura da "Mensagem de Dilma", em cerimônia pública, cercada de lideranças religiosas e parlamentares evangélicos, que assegurava a não interferência do Executivo com projetos que alterassem a legislação do aborto. Essa dinâmica de pressão e trocas também foi verificada por Machado (2006) na pesquisa sobre atuação de parlamentares evangélicos do RJ.

A Igreja Católica foi outro ator fundamental em todos os momentos da cobertura, desde o debate promovido pela CNBB, quando esse estopim se acendeu pela primeira vez, até a véspera do segundo turno, com a declaração do Papa recomendando evitar candidatos favoráveis ao aborto. Pronunciamentos de representantes de sua hierarquia perduraram em todo o processo, em contraste com o foco da imprensa nos evangélicos, que cessou após a candidata Dilma Rousseff assinar a "Carta aos brasileiros".

A esse respeito, é possível concluir, como Oro (2003), que, malgrado a separação oficial entre Igreja e Estado, não se observa a autonomia entre os campos religioso e político, mas diversas áreas de trânsito e passagem. A presente análise do último processo eleitoral sugere uma “... luta por ampliar a dimensão religiosa do espaço público e não laicizá-lo" (J.J. Carvalho apud Oro, 2003, p.64). Essa situação é relativa à cultura brasileira e ao lugar que nela ocupa a dimensão religiosa, como afirma o próprio Oro (2003).

Esse aspecto leva ao ponto referente às crenças e aos valores que afetaram o processo eleitoral. Entre vários exemplos registrados na imprensa, destaca-se o vídeo anti-PT, produzido pelo pastor Paschoal Piragine Júnior, e sua ampla veiculação pela Internet, além da dita fuga de eleitores religiosos, o que tirou de Dilma Rousseff a chance de eleição no primeiro turno, por conta de sua posição favorável à legalização do aborto. Quando valores religiosos assumem tal relevância no espaço público, questiona-se a interpretação mais consagrada da teoria da secularização, segundo a qual a religião, com o advento da modernidade, é confinada à esfera do privado (Berger, 1985). Autores como Giumbelli (2002a), embora reconhecendo 
processo histórico da secularização, questionam o potencial heurístico desse conceito para a pesquisa. Há diferenças entre as posições assumidas por instituições e por sujeitos individuais no tocante à secularização. Segundo Berger (2001, p. 12), a Igreja Católica estaria em rota cheia de nuances entre rejeitar e adaptar-se ao processo de secularização. Ainda conforme esse autor, a posição da Igreja Católica sobre aborto e contracepção baseiase em uma lógica religiosa. Para além das instituições, Berger (2011, p. 10) afirma que a secularização no nível social não está relacionada à secularização no nível da consciência individual.

De acordo com Duarte (2006), considerando a história das instituições religiosas no mundo ocidental moderno e das práticas públicas e privadas associadas, a vida familiar e a vida religiosa foram alocadas no mundo privado. O regime moral permite distinguir as congregações laicas e as religiosas. Igrejas e congregações teriam firmado pactos implícitos com a modernidade para lidar com os valores subjetivistas da escolha e os valores naturalistas da racionalidade científica.

A restrição do fenômeno religioso a uma esfera é uma invenção ocidental moderna, em contraste com contextos tradicionais em que a religião regula a totalidade cósmica e social (Giumbelli, 2002a). Com respeito à observação de Berger (2011) sobre a diferença entre o processo de secularização e a secularização das consciências, no contexto brasileiro, a religiosidade dos candidatos é atributo valorizado no imaginário político, conforme se depreende de survey realizado em 1998 (Machado, 2006, p. 80). A explicitação de práticas religiosas foi um elemento bastante acionado pelos candidatos José Serra e Dilma Rousseff no segundo turno, conforme o registro das notícias. Retomando a polêmica sobre o aborto nas eleições, uso uma declaração obtida por Machado (2006) de um político evangélico da base aliada ao presidente Lula no primeiro mandato. O deputado evangélico pretendia alertar suas comunidades contra falsos boatos da época de campanha, como, por exemplo, que Lula iria perseguir evangélicos, fazer o primeiro casamento homossexual e permitir o abor- to indiscriminado. Esse deputado também criticou a posição da Igreja Católica quanto ao planejamento familiar. Os itens referidos na entrevista desse político revelam os temores por parte dos evangélicos quanto à implantação de um regime moral considerado dissoluto, como o denunciado no vídeo do pastor batista Pascoal Piragine Júnior, moralidade ainda mais rigorosa nos grupos pentecostais (Berger, 2001; Machado, 2000). Em um país onde se assinala o descrédito pela política tradicional (Machado, 2006), as opiniões sobre aborto provenientes de uma pessoa investida de um cargo público de direção importam porque foram travestidas em índices de sua moralidade.

Analisando a cobertura da imprensa sobre a campanha eleitoral de 2010, pode-se afirmar que a posição pessoal de candidatos acerca do aborto e sua atuação pública em questões que envolveram o tema, bem como as posições de partidos políticos foram levantadas em uma dinâmica de acusações que remete às pesquisas clássicas sobre bruxaria (Evans-Pritchard, 2005). Essa constatação leva a perguntar por que essa dinâmica se forma a partir de colocações sobre o aborto. Qual a importância do aborto como signo nessa controvérsia?

Artigo de Machado (2000) aponta o aborto como tema-chave na disputa religiosa, comparando a abordagem dos periódicos publicados pela IURD e pela Assembleia de Deus no tocante ao tema, no contexto da visita do Papa ao Brasil em 1997 e da votação na Comissão de Constituição de Justiça da Câmara dos Deputados do projeto de lei sobre a obrigatoriedade de atendimento pelo SUS dos casos de aborto previsto em lei. Diversos líderes da IURD fizeram declarações favoráveis ao aborto legal, com críticas à ingerência católica sobre interrupção de gravidez e planejamento familiar. E, mesmo na Assembleia de Deus, igreja mais tradicional e conservadora do campo pentecostal, verificou-se certa flexibilização das posições, sendo publicados artigos de posição contrária ao aborto em qualquer situação, mas também de artigos com defesa da interrupção de gravidez prevista em lei como um direito de atendimento à saúde que beneficiaria as mulheres pobres. 
Pesquisas quantitativas verificam a existência de oposição ao aborto disseminada entre todas as religiões pesquisadas no Brasil, conforme dados do Estudo Eleitoral Brasileiro de 2002. A concordância com a afirmativa "o aborto deve ser proibido em qualquer situação" é maior nos grupos neocristãos, 65,4\% (mórmons, adventistas e Testemunhas de Jeová), seguida pelos evangélicos pentecostais $46,8 \%$, católicos $37,6 \%$ e evangélicos não pentecostais 32,1\% (Nishimura, 2004). A partir dos dados do survey "Novo Nascimento", realizado entre evangélicos da região metropolitana do Rio de Janeiro, Mariz (1998) sugere que as variáveis renda e nível de instrução afetam significativamente esses resultados: quanto maior a renda, maior a aceitação do aborto, e, principalmente, quanto maior o nível de instrução, em particular entre os que atingem o nível superior de educação. Valores mais individualistas são favorecidos entre os de maior instrução.

Artigo de Duarte e outros (2006), partindo do subjetivismo e do naturalismo como valores estruturantes de um ethos privado não confessional, aponta para as dificuldades de se compreenderem as declarações e atos a respeito do aborto no mundo moderno: o aborto ameaçaria os valores cosmológicos da natureza e da vida. Haveria o confronto entre o subjetivismo, que consideraria a dimensão da escolha por parte da mulher, com o direito de decisão sobre seu próprio corpo, e o naturalismo, na resistência ao aborto decorrente de um respeito genérico à vida. A rejeição ao aborto como atentado ao caráter sagrado da vida pode estar associada a uma prevalência do valor da natureza sobre o valor da subjetividade entre segmentos menos individualizados da sociedade. Do ponto de vista do nascituro, o subjetivismo o definiria como pessoa desde o momento da concepção, o que representaria um recobrimento do subjetivismo sobre o naturalismo.

Portanto, é possível concluir que, por seu aspecto dramático, envolvendo dilemas morais quanto à liberdade do sujeito e o direito à vida, $\mathrm{O}$ aborto se torna um ícone manipulável em disputas como a campanha presidencial, e foi um ele- mento fundamental na definição de parte de diversos eleitores sobre em quem confiar para dirigir os destinos do país.

Recebido para publicação em07 de fevereiro de 2012 Aceito em 05 de agosto de 2013

\section{REFERÊNCIAS}

ARDAILLON, Danielle. O lugar do íntimo na cidadania de corpo inteiro. Estudos Feministas, Florionópolis, UFSC, v.5, n.2, p.376-388, 1997.

BERGER, Peter. A dessecularização do mundo: uma visão global. Religião e Sociedade, Rio de Janeiro, v.21, n.1, p.923, 2001.

O dossel sagrado: elementos para uma teoria sociológica da religião. São Paulo: Paulus, 1985.

DUARTE, Luiz Fernando Dias. Ethos privado e modernidade: o desafio das religiões entre indivíduo, família e congregação. In: DUARTE, L.F.D; HEILBORN, Maria Luiza; BARROS, Myriam Lins de; PEIXOTO, Clarice (Org.) Família e religião. Rio de Janeiro: Contracapa. 2006. p.51-87.

DUARTE, Luiz Fernando Dias; GOMES, Edlaine de Campos; JABOR, Juliana; LUNA, Naara. Família, reprodução e ethos religioso - subjetivismo e naturalismo como valores estruturantes. In: DUARTE, Luiz F.D.; HEILBORN, Maria Luiza; BARROS, Myriam Lins de; PEIXOTO, Clarice (Org.) Família e religião. Rio de Janeiro: Contracapa. 2006. p.15-49.

EVANS-PRITCHARD, E.E. Bruxaria, oráculos e magia entre os Azande. Rio de Janeiro: Jorge Zahar, 2005.

FONTES, Maria Lucineide Andrade. O enquadramento do aborto na mídia impressa brasileira nas eleições 2010: a exclusão da saúde pública do debate. Ciência e Saúde Coletiva, Rio de Janeiro, v.17, n.7, p.1805-1812. 2012.

GIUMBELLI, Emerson. O fim da religião: dilemas da liberdade religiosa no Brasil e na França. São Paulo: Attar, 2002a.

. Para além do "trabalho de campo": reflexões supostamente malinowiskianas. Revista Brasileira de Ciências Sociais,São Paulo, v.17, n.48, p.91-107, 2002b.

GOMES, Edlaine de Campos. A religião em discurso: a retórica parlamentar sobre o aborto. In: DUARTE, L.F.D.; GOMES, E. C. MENEZES, R. A.; NATIVIDADE, M. (Org.) Valores religiosos e legislação no Brasil: a tramitação de projetos de lei sobre temas morais controversos. Rio de Janeiro: Garamond/FAPERJ, 2009. p.45-70.

GOMES, Edlaine de Campos; MENEZES, Rachel Aisengart. Aborto e eutanásia: dilemas contemporâneos sobre os limites da vida. Physis: Revista de Saúde Coleti$v a$, Rio de Janeiro, v.17, n.1, p.77-103, 2008.

LOPES, Cristiano Aguiar. A manipulação do aborto. $\mathrm{Ob}$ servatório da Imprensa, v.18, n.812, 2010. Disponível em: <http://www.observatoriodaimprensa.com.br/news/view/ a-manipulacao -do-aborto>. Acesso em: 30 nov. 2011.

LUNA, Naara. A polêmica do aborto e o $3^{\circ}$ Programa Nacional de Direitos Humanos. Dados: revista de Ciências Sociais, Rio de Janeiro, v.57, n.1, p. 239-277, 2014.

MACHADO, Lia Zanotta. Feminismo em movimento. São Paulo: Francis, 2010. 
MACHADO, Maria das Dores Campos. Política e religião: a participação dos evangélicos nas eleições. Rio de Janeiro: FGV, 2006.

O tema do aborto na mídia pentecostal: notas de uma pesquisa. Estudos Feministas, Florionopolis, v. 8 , n.1, p.200-211, 2000.

Aborto e ativismo religioso nas eleições de 2010. Revista Brasileira de Ciência Política, Brasília, n.7, p.2554. 2012.

MARIZ, Cecilia Loreto. A opinião dos evangélicos sobre o aborto. In: FERNANDES, Rubem César et al. (Org.) Novo nascimento; os evangélicos em casa, na igreja e na política. Rio de Janeiro: Mauad, 1998. p.211-223.

MELO, Jacira. A polêmica do aborto na imprensa. Estudos Feministas, Florionópolis, v.5, n.2, p.406-412. 1997.

A cobertura da imprensa com relação ao tema do aborto. Anotações. In: PEREIRA, Irotildes G. (Org.) Aborto legal: implicações éticas e religiosas. São Paulo: Loyola, 2002. p.125-128. (Cadernos Católicas pelo Direito de Decidir).
NISHIMURA, Katia Mika. Conservadorismo social: opiniões e atitudes no contexto da eleição de 2002. Opinião Pública, Campinas, v.9, n.2, p.339-367, out. 2004.

ORO, Ari Pedro. A política da Igreja Universal e seus reflexos nos campos religioso e político brasileiros. Revista Brasileira de Ciências Sociais, São Paulo, v.17, n.53, p.5369, out. 2003.

PIERUCCI, Antônio Flávio. Eleição 2010: desmoralização eleitoral do moralismo religioso. Novos Estudos CEBRAP, São Paulo, v.89, p.5-15, mar. 2011.

RAMOS, Jair de Souza. Toma que o aborto é teu: politização do aborto em jornais e na web durante a campanha presidencial de 2010. Revista Brasileira de Ciência Política, Brasília, n.7, p.55-82, 2012.

ROCHA, Maria Isabel Baltar da. A discussão política sobre aborto no Brasil: uma síntese. Revista Brasileira de Estudos de População, Rio de Janeiro, v.23, n.2, p.369-374, jul./dez. 2006. 


\section{THE ABORTION CONTROVERSY AND THE PRESS IN THE 2010 ELECTION CAMPAIGN}

\author{
Naara Luna
}

This article analyzes the discourse about abortion diffused by the media during the 2010 election campaign. A qualitative, documental study was conducted using systematic data collection from the in print coverage of $O$ Globo newspaper, and a random search in various media that approached both the subject and the relation between election controversies and religion during September and October 2010. The study focuses on the discourse presented in articles, and on repeated topics and actors. We emphasize the participation of religious groups in different positions not regarding abortion, but rather electoral support and alliances. The analysis shows that the subject's increased frequency in the media did not prompt a debate on the abortion problem in Brazilian society; instead, it was used as an accusing category and a divide between candidates, particularly in the presidential campaign. In contrast with the highlight given to the Catholic Church in similar events, the media revealed political and religious actors previously obscure.

KeYwords: Abortion. 2010 Elections. Catholic Church. Evangelicalism. Press.

\section{LA CONTROVERSE SUR L'AVORTEMENT ET LA PRESSE AU COURS DE LA CAMPAGNE ÉLECTORALE DE 2010}

\author{
Naara Luna
}

Cet article fait l'analyse du discours sur l'avortement paru dans la presse pendant la campagne électorale de 2010. Une recherche qualitative à caractère documentaire a été réalisée à partir du relevé systématique de la première page du Journal $O$ Globo et d'une recherche aléatoire dans les journaux et revues qui ont abordé la question ainsi que le lien existant entre les polémiques électorales et la religion au cours des mois de septembre et d'octobre 2010. L'accent a été mis sur le discours présenté dans ces articles, les sujets et les acteurs qui revenaient constamment. Nous soulignons la participation de groupes religieux ayant des prises de position distinctes non pas par rapport à l'avortement mais par rapport aux appuis et aux alliances politiques. L'analyse démontre que, bien que le thème ait été abordé plus fréquemment dans les médias, il n'y a pas eu de véritable débat sur le problème de l'avortement dans la société brésilienne. Il a cependant été utilisé comme élément d'accusation et de division entre les candidats, essentiellement dans la campagne présidentielle. Alors que l'Eglise Catholique est mise en évidence dans de semblables circonstances, ce sont des acteurs politiques et religieux qui avant restaient dans l'ombre qui ont été dévoilés par les médias.

MoTS-CLÉs: Avortement. Elections de 2010. Eglise catholique. Évangéliques. Presse.

\footnotetext{
Naara Luna - Doutora e pós-doutora em Antropologia. Professora adjunta do Departamento de Ciências Sociais e Extensão Rural (DCS) do Instituto de Ciências Humanas e Sociais da Universidade Federal Rural Rio de Janeiro (UFRRJ) e da (recém-criada) Pós-Graduação em Ciências Sociais da UFRRJ. Suas áreas de interesse são: Natureza e Cultura, Antropologia da Pessoa, do Corpo e da Saúde, Antropologia do Parentesco, Antropologia da Ciência, Antropologia da Religião. Publicações recentes: Aborto no Congresso Nacional: o enfrentamento de atores religiosos e feministas em um Estado laico. Revista Brasileira de Ciência Política (Impresso), p. 83109, 2014; A construção do fato científico: as representações sobre células-tronco. Revista de Antropologia (USP. Impresso), v. 56, p. 321-358, 2013; $O$ direito à vida no contexto do aborto e da pesquisa com célulastronco embrionárias: disputas de agentes e valores religiosos em um estado laico. Religião \& Sociedade (Impresso), v. 33, p. 71-97, 2013.
} 
